\title{
Race, Ethnicity, and Youth Perceptions of Criminal Injustice
}

\author{
John Hagan \\ Northwestern University \\ American Bar Foundation
}

\author{
Carla Shedd \\ Northwestern University \\ American Bar Foundation
}

Monique R. Payne

DePaul University

This paper advances a comparative conflict theory of racial and ethnic similarities and differences in youth perceptions of criminal injustice. We use HLM models to test six conflict hypotheses with data from more than 18,000 Chicago public school students. At the micro-level African American youth are more vulnerable to police contacts than are Latinos, who are more at risk than whites, and there is a corresponding gradient in minority group perceptions of injustice. When structural sources of variation in adolescents' experiences are taken into account, however, minority youth perceptions of criminal injustice appear more similar to one another, while remaining distinct from those of white youth. At the micro-level, Latino youth respond more strongly and negatively to police contacts, even though they experience fewer of them. At the macrolevel, as white students in schools increase cross-sectionally, perceptions of injustice among both African American and Latino youth at first intensify and then ultimately abate. Although there are again signs of a gradient, African American and Latino responses to school integration also are as notable in their similarities as in their differences. Reduced police contacts and meaningful school integration are promising mechanisms for diminishing both adolescent African American and Latino perceptions of criminal injustice.

$\mathrm{C}$ onflict theory historically has stressed the roles of group threat, subordination, and powerlessness in explaining crime and its control in America (Turk 1969; Quinney 1970; Chambliss and Seidman 1971). Subsequent statements of conflict theory have more specifically emphasized the salience of race in grounding these group relationships (Liska et al. 1985;

Direct all correspondence to John Hagan, Department of Sociology, Northwestern University, 1810 Chicago Avenue, Evanston, IL 60208 (jhagan@abfn.org). Earlier versions of this paper were presented at the annual meeting of the American Society of Criminology in Denver, CO, November 2003, and the Conference on Crime, Justice, and Inequality at The Ohio State University, July 2004. This material is based upon work supported by the
Hawkins 1987; Mitchell and Sidanius 1995; Walker, Spohn, and DeLone 2000). Racial disproportionalities in American rates of arrest, imprisonment, and capital punishment are indisputable (Blumstein 1982; Tonry 1995; Mauer 1999; Kennedy 1997), although debate persists about the sources of these disproportionalities (Wilbanks 1987; Mann 1993; Chambliss 1999).

American Bar Foundation (Chicago, IL) and the National Science Foundation under Grant No. SES0215551 to the National Consortium on Violence Research. Any opinions, findings, and conclusions or recommendations expressed in this material are those of the authors and do not necessarily reflect the views of the National Science Foundation. We thank Jerry Jacobs, the anonymous reviewers for the American Sociological Review, and Professor Mary Pattillo. 
African Americans overwhelmingly perceive these differences as unjustifiable (Hagan and Albonetti 1982; Wortley, Hagan, and Macmillan 1997; Weitzer 1999; Brooks 2000; Brooks and Jeon-Slaughter 2001; Bobo and Johnson 2004). Yet despite the massive numbers of African American youth who come into conflict with the criminal law and perceive it as unjust, we know relatively little about how this conflict is socially structured and extends to other ethnic groups.

There is growing concern that perceived injustice itself causes criminal behavior (Tyler 1990; Mann 1993; Russell 1998; LaFree 1998), which adds urgency to developing a better understanding of racial and ethnic differences in perceptions of criminal injustice. We use Chicago public-high school survey data to explore how perceptions of criminal injustice vary across Latino, African American, and white youth, and how these perceptions may be linked to variation in the racial integration of American schools. Our goal is to identify comparative processes of similarity and difference in racial and ethnic perceptions of criminal injustice among adolescents in American society.

\section{RACE, DISADVANTAGE, AND PERCEIVED INJUSTICE}

Perceptions of injustice are systematic and widespread in American society: for example, African Americans perceive inequality and discrimination in education, employment, health care, and housing (Feagin and Sikes 1994; Dawson 1994; Hochschild 1995; Schuman, Steeh, Bobo, and Krysan 1997). The majority of white Americans believe that African American economic inequality results from motivational weaknesses, while most African Americans believe that this inequality is the result of white racism (Bobo and Kluegel 1997). Orlando Patterson (1997:15) emphasizes that a long history of public dishonor and ritualized humiliation of African Americans by EuroAmericans has generated deep distrust, but as we discuss later in greater detail, Patterson also argues that the American racial divide is more complicated than this.

There is compelling evidence that race is considerably more important than social class for explaining variation in urban American arrest rates (Liska et al. 1985), and this supports the importance recently attached to race in a conflict theory of crime. Still there are suggestions that micro- and macro-level economic disadvantages can be further root causes of perceived criminal injustice. For example, using a national sample, Hagan and Albonetti (1982) find that unemployed members of the "surplus population" and African Americans perceive higher levels of criminal injustice. In an innovative study with micro- and macro-measures, Sampson and Bartusch (1998) find that individual-level socioeconomic status is positively linked to satisfaction with the police; that concentrated neighborhood disadvantage increases dissatisfaction with the police; and that the latter concentration of poverty further accounts for racial differences at the individual level in dissatisfaction with the police.

Sampson and his collaborators' unique contributions to the research literature on perceived injustice are especially noteworthy. First, Sampson and Lauritsen (1997:364) observe that it is potentially misleading to think of differences in perceived injustice as neatly divided in binary, black/white terms. They emphasize that immigration from Mexico and Cuba in particular is reshaping many American cities. The implication is that the future picture of criminal justice processing may be closely tied to the experiences of racial and ethnic groups that are largely absent from criminological research. The broad sociological implications of this point are underlined, for example, in intergenerational research by Portes and Rumbaut (2001) on changes in American immigration and social stratification.

Second, in moving beyond the individual level to contextualize issues of racial disparity, Sampson and Bartusch (1998:871) suggest that we conceptualize differences in racial orientations in terms of macro-level "cognitive landscapes" at the neighborhood and community level (see also Sampson, Raudenbush, and Earls 1997). A similar point is made in post-Brown vs. Board of Education educational research on the macro-level effects of school integration on student attitudes (Johnson, Crosnoe, and Elder 2001). We pursue these points later in the paper.

Meanwhile, Collins (1997) and Cose (1994) provide compelling accounts of feelings of discontent and distrust among middle-class African American professionals. These accounts stress that affluent and better-educated blacks view African Americans as much worse off than 
white Americans (Dawson 1994; see also Hochschild 1995). Middle-class African Americans are especially impatient with civil rights reform and enforcement (Schuman, Steeh, Bobo, and Krysan 1997). Brooks and JeonSlaughter (2001:2) observe that this class or education-by-race interaction is further reflected in the widespread suspicions of economically and educationally advantaged African Americans about the American legal system (see also, e.g., Peek, Lowe, and Alston 1981; Weitzer and Tuch 1999).

Yet when studies of perceived criminal injustice separate respondents by race, the resulting findings with regard to economic disadvantage are inconsistent. Some studies indicate that income reduces perceived injustice among African Americans, other studies report that class position increases this sense of injustice among African Americans, and still other research finds no income effects at all, regardless of race (cf. Hagan and Albonetti 1982; Henderson et al. 1997; Wortley, Hagan, and Macmillan 1997; Weitzer and Tuch 1999; Brooks and Jeon-Slaughter 2001; Tuch and Weitzer 1997). The possibility that better- rather than less-well-off African Americans perceive greater injustice is an apparent exception to the conflict theory prediction that economic disadvantage should heighten perceptions of injustice. The variation in the fore-going findings suggests that something more than simple, absolute economic deprivation is involved in racial perceptions of criminal injustice, and we argue that this involves variation in frames of reference and comparison that a more nuanced conflict theory can incorporate.

\section{TOWARD A COMPARATIVE CONFLICT THEORY OF PERCEIVED CRIMINAL INJUSTICE}

Although leading conflict theorists of crime such as Chambliss and Seidman (1971:475) framed their foundational hypotheses in class terms, more recently Chambliss (1999:75) emphasizes that intense surveillance of black neighborhoods, the relative absence of surveillance of white neighborhoods, and differences in punishments for white and black offenders reinforce perceptions that the system is racist in ways designed to more specifically oppress black people. Bobo and Johnson's (2004:152) survey of the literature similarly concludes that an increasing number of scholars see U.S. criminal justice policies as deliberate (albeit decentralized and loosely coordinated) efforts to reassert control and dominance over African Americans.

Although there is continuing debate in life course research about when or even whether such politically sensitive beliefs (in this case about criminal justice) ever fully crystallize, there nonetheless is agreement that adolescence is a critical formative period for such development (Flanagan and Sherrod 1998; Niemi and Hepburn 1995). Bobo and Johnson (2004:155) emphasize that political and social values emerge early in life and are persistent; and they more specifically conclude that views about the criminal justice system are rigid and resistant to change in adulthood. We will see below that middle adolescence is for minority youth a significant time of change in these perceptions. It is appropriate, therefore, that conflict theory and related research on race and crime focus on the formative teenage years.

Our conflict theory of perceived criminal injustice thus begins with the hypothesis that during the teen years race is a salient comparative point of reference for understanding perceptions of criminal injustice in America, so that

Hypothesis 1: African American racial status has a net direct effect on adolescent perceptions of criminal injustice.

Davis (1959) places this hypothesis within a comparatively framed conflict theory by noting that when a deprived person contrasts him or herself with a non-deprived person, the resulting attitude can be called "relative subordination." The concept of relative subordination implies reference groups, a concept Runciman (1966:9) sees as derived from the truism that people's attitudes, aspirations, and grievances largely depend on the frame of reference within which they are conceived (see also Merton and Rossi 1957; Stouffer 1949).

Portes and Rumbaut (2001:47) recently have highlighted the racial framing of this issue by noting that skin tone is a paramount criterion of social acceptance in America, and that race often supersedes the influence of class background, religion, or language. They make the further comparative argument that there is a 
racial gradient in U.S. culture, so that the darker a person's skin is, the greater his or her social distance from dominant groups, and the more difficult it is to make personal qualifications count. For conflict theorists of race and crime (Hawkins 1987:736), social dissimilarity and distance are associated with powerlessness and threat, with African Americans seen by dominant groups as less powerful and more threatening to whites than Latinos. This sense of differential threat may further derive from the longer history involving slavery of blacks in the United States, as contrasted with the more recent and growing presence of Latinos in American cities such as Chicago.

The implication for a comparative conflict theory of crime is that Latinos occupy a disadvantaged middle ground where they are a less comprehensive and intensive focus of criminalization efforts than African Americans, but more at risk than whites. This leads to a second hypothesis that

Hypothesis 2: There is a racial gradient to the effect of race/ethnicity on adolescent perceptions of criminal injustice, with African American racial status having a more pronounced comparative effect than Latino ethnic status on perceptions of criminal injustice, but with Latino ethnic status still leading to perceived injustice.

However, there is little prior research on Latino perceptions of the criminal justice system, and the few surveys that have considered views of Latinos have produced equivocal findings (see Brooks and Jeon-Slaughter 2001:2n.).

Given the dearth of comparative research that includes African Americans and Latinos along with whites, it may be important to take our investigation beyond the main effect of the racial/ethnic gradient just hypothesized. While police attention to African American youth is frequent and therefore familiar (Anderson 1999; Young 2004), little is known about how Latino youth respond to their experiences with the police - perhaps in part because their experiences with the police are assumed to be less common. A study sampling Hispanics (Carter 1985) reports that respondents' attitudes toward the police are good until they have experience with them (494-95), but that as contact with the police increases, expectations for them decrease (498; see also Skogan et al. 2002). There may be nonadditive differences as well as similarities in Latino and African American experiences with the police that should be taken into account in making comparisons. Taking differences into account may actually prove to be a key to uncovering more fundamental commonalities, so that

Hypothesis 3: The difference in Latino and African American perceptions of criminal injustice will be reduced when relative differences in experiences of police contacts are taken into account.

The implication of this hypothesis is that it may be important to develop a more nuanced understanding of similarities as well as differences in adolescent African American and Latino perceptions of criminal injustice.

Neighborhood, school, and workplace experiences provide further contexts of comparative racial and ethnic subordination. The range and focus of such comparative experiences can be crucial (Hagan and Bernstein 1979; Peterson and Hagan 1984). Brooks (2000) uses a comparative perspective to explain the unexpected outrage among more advantaged African Americans on the topic of discrimination. He suggests (1218-19) that low-income African Americans are more inclined to restrict their frame of reference to their immediate community when evaluating their experiences. The concentrated separateness of the African American urban experience may actually make the experience of police harassment so familiar that it becomes an "experience of the expected" and produces less outrage than would otherwise be predicted. Massey and Denton (1993) describe the physical separation of the great majority of the African American poor as the "forgotten factor" in American race relations.

Self-categorization theorists (Turner et al. 1987) see actors as locating themselves along a range from individual to group membership. Brooks (2000:1219) similarly suggests that successful blacks develop multiple reference groups, and that this allows them to compare more easily their outcomes to whites and other racial groups, so that notwithstanding their own successful outcomes, they may be even more inclined to perceive injustice as long as blacks as a group fare poorly. An awareness of the possibility of improved outcomes may lead 
familiar and even expected experiences to be understood and perceived as more outrageous.

Thus these feelings of deprivation may also be influenced by the level of exposure to other and more advantaged groups in a surrounding neighborhood, at work, or in school. Educational research emphasizes the likely significance of the racial/ethnic composition of schools on not only the academic but also the social lives of students. Although there is evidence that interracial contact in schools can improve racial attitudes (e.g., Ellison and Powers 1994), there also is evidence of in-group preferences suggesting that going to school with other racial and ethnic groups can result in isolation, suspicion, and hostility (see Hallinan and Williams 1987, 1989; Schofield 1979). Recent work (Johnson, Crosnoe, and Elder 2001) indicates that samerace/ethnicity school composition enhances educational attachment, while increased exposure to other racial and ethnic groups weakens this attachment. The implication is that increased cross-group contact can be a source of conflict.

The role of a broadening frame of comparative reference in understanding African American perceptions is highlighted in Orlando Patterson's (1997) analysis of The Ordeal of Integration. Patterson observes that in earlier eras of racial segregation, African Americans were separated - physically, occupationally, and culturally - and that this allowed little opportunity for conflict (51). When limited steps toward integration began to break down barriers, however, Patterson argues that the consequences of separation became more apparent for those who were kept apart and that the frustrations of these experiences could now be more freely perceived and expressed. This can explain how even though academic achievement of minority students might improve in integrated schools (Entwisle and Alexander 1992; Roscigno 1998), interracial attitudes might simultaneously worsen.

"Put briefly," Patterson writes, "as the relations between the previously segregated groups change, becoming objectively better for AfroAmericans, they will be experienced by AfroAmericans as getting much worse even as they are genuinely seen by Euro-Americans to be improving" (54). It is not the experience of discrimination that is changing so much as the context in which it is perceived. Patterson refers to this contemporary condition as "the objective paradox of integration" and to its hostile consequences as "the outrage of liberation."

Brooks (2000) places the general linear relationship between opportunity and grievance within the numerically measurable context of residential and occupational segregation. He suggests that middle-class African Americans moving more widely in the mainstream of American life may be caught off guard when their status does not protect them from police harassment, while their peers living and working in measurably more homogeneous racial environments may be conditioned to expect less. The latter can result in the "experience of the expected" we noted earlier. Alternatively, Brooks indicates that African Americans in integrated (or mostly white) settings may have more occasions to observe racial bias, and he further notes that this can place middle-class and upperclass blacks in a heightened state of sensitivity to differential treatment (1256-57). This is consistent with Patterson's (1997:51) observation that as Afro- and Euro-Americans come into more frequent contact, the possibility for conflict is bound to increase.

Schools are a likely comparative context in which adolescent perceptions are formed. Runciman (1966:25) suggests that there are subversive potentialities of knowledge that derive from the capacity of schooling to act as an independent influence on reference groups and thereby create relative deprivations where none existed before. The implication is that the experience of integration with whites may be a key macro-level mechanism driving perceived injustice, leading to a fourth comparative conflict theory hypothesis for adolescents that

Hypothesis 4: The comparative effect of African American racial status on adolescent perceptions of criminal injustice increases with the proportion of white youth present as comparative points of reference in the schools.

Yet there may be more to this hypothesis than a simple linear, black-and-white formulation implies. In reviewing the writings of African Americans on race relations, Brooks (2000:1256) notes that scholars speculate that better-off blacks are more concerned about the status of blacks compared to other groups as opposed to maintaining a specifically black reference group. This pluralization of reference 
groups invites an inclusion of Latinos and a macro-level racial gradient into our comparative conflict analysis, and thus may imply the following added hypothesis:

Hypothesis 5: The racial gradient of racial/ethnic effects on perceived adolescent criminal injustice results in African American youth being comparatively more affected than Latino youth by the proportion of white youth in their schools.

The point, of course, is that both African and Latino American students are involved in comparing their treatment to that of white students. Again, it will be important in assessing this hypothesis to take into account differences in responses to police contacts; but the implication of this hypothesis is that especially for African American youth, it may be the novelty of the reduction in separateness and isolation that is as much or more salient than the familiar problem of police harassment.

Finally, Runciman (1966:19) makes the potentially important assertion that in a pure comparative model of perceived social and economic outcomes, there will be observable points where the likelihood of dissatisfaction will reach maximum and minimum levels. He further notes that Merton and Rossi (1957:7) expect the racially poignant relationship between occupational opportunity and satisfaction to be curvilinear, and that this requires the sociologist to work out toward the conditions under which the observed linear relationship fails to hold.

Merton and Rossi's prediction bears an interesting connection to the idea that there are tipping points in processes of residential integration and segregation. While the notion of tipping points usually is used pessimistically to predict the boundary of unsuccessful minority representation in previously non-minority communities (Schelling 1971), a more optimistic hope is that the impact of integration on perceived injustice eventually can reach a point where inclusion with the majority group begins to become more benign for perceptions of injustice. Thus our last and perhaps most policy relevant hypothesis is that

Hypothesis 6: There is a tipping point to the incremental comparative effect of proportion of white youth in schools on racial/ethnic perceptions of criminal injustice, so that a point may ultimately be reached where minority-group member perceptions of injustice begin to abate.

We cannot estimate in advance what this specific tipping point might be, and there is the further concern that the public schools' general failure to prevent white flight and to be meaningfully integrated place an upper bound on the possibilities of reaching such a tipping point. Nonetheless, if a tipping point can be established, it would have obvious policy relevance. It would suggest that there is a point at which the ordeal of integration that Patterson describes begins to become more benign. Patterson's commitment to the ideal of integration implies his belief that such a tipping or turning point exists.

\section{THE CHICAGO PUBLIC SCHOOL SETTING}

Our test of the above conflict hypotheses is based on a survey undertaken in the fall of 2001 by the Consortium on Chicago School Research (2002). It is important to consider why a survey at this historical juncture in a large American city is timely for the purposes of assessing a comparative conflict perspective. It is now a half-century since Brown v. Board of Education ${ }^{1}$ declared that segregated schools for black and white students must be eliminated, and just over a quarter century since Milliken v. Bradley ${ }^{2}$ marked a reversal in court mandated efforts at city/suburban desegregation that might have made real integration a growing reality in major American cities. Increasingly, the U.S. Supreme Court has authorized termination of desegregation orders.

In January, 2003, a Northern District of Illinois federal district judge threatened to vacate a 1980 consent decree ${ }^{3}$ aimed at desegregating the Chicago public schools, saying that "the idea that we have a decree . . . seems to me to be chasing good money after an issue that is no longer viable or necessary for anybody's consideration." ${ }^{4}$ This view was grounded in a

\footnotetext{
${ }^{1}$ Brown v. Board of Education of Topeka, 347 U.S. 483 (1954).

${ }^{2}$ Milliken v. Bradley, 418 U.S. 717 (1974).

3 Student Desegregation Plan for the Chicago Public Schools, 2 (1981).

${ }^{4}$ United States of America v. Board of Education of Chicago, 80 U.S. 5124 (2003).
} 
supreme court decision that desegregation is not mandated when the racial composition of schools is a result of demographic shifts rather than segregative acts. ${ }^{5}$ Opponents of the move to vacate the 1980 decree, which involved the creation of magnet schools and other innovative remedies, argue that the issue is more one of the efficacy of the decree, and that time is required to make a factually informed assessment of the likely benefits of the consent decree. ${ }^{6}$ The court has now set the end of the 2005-06 school year for reconsideration of the Chicago consent decree (see Olszewski and Little 2004).

School segregation has been increasing in the United States since the 1980s (Frankenberg and Lee 2002; Frankenberg, Lee, and Orfield 2003). Chicago has the smallest percentage of white students and the largest percentage of students living in poverty among the nation's five largest school districts. The proportion of white students in Chicago public schools has decreased from 19 percent in 1980 to 9.2 percent in 2003. During this same period the proportion of black students also has decreased from just over 60 percent $(60.6 \%)$ to about 50 percent (50.9\%), while with immigration and a higher birth rate, the proportion of Latino/Hispanic students is now more than one third (36.4\%).

The conflicts accompanying changes in educational and residential segregation in Chicago are played out through the lives of young people and prominently feature encounters with the law, often in ways that link the schools with the police and justice system. Nearly every Chicago public school has one or more police officers stationed in and patrolling its hallways, and in 1992 the Chicago City Council passed a "gang loitering" law, which permitted police to arrest anyone whom they suspected of being a gang member for congregating with no appar-

\footnotetext{
${ }^{5}$ Pasadena City Board of Education v. Spangler, 427 (1976) 424.

${ }^{6}$ Memorandum of Amici Curiae-American Civil Liberties Union of Illinois, Chicago Lawyers Committee for Civil Rights Under Law, Inc., Mexican-American Legal Defense and Education Fund, National Association for the Advancement of Colored People-Chicago Southside Branch, and National Lawyers Guild-Chicago Chapter, March 20, 2003.
}

ent legal purpose. The crackdown resulted in more than 42,000 arrests before a string of court decisions ruled the law unconstitutional (Hirschfield 2003). The sheer volume of these arrests attests to the "experience of the expected" noted earlier. In 1997, Chicago enacted a "reciprocal records agreement," which requires the city police department to release to each school's administrators on a daily basis the names of youth arrested off campus (Chicago Public Schools 1997). These arrests can be used to justify school suspension and expulsion decisions. So there is reason to expect an interconnection of school and justice system experiences.

By the 1960s, Gerald Suttles (1968) was writing about the racially and ethnically segmented neighborhoods of Chicago and resultant conflicts among groups of youth and often between youth and the police. One notorious practice in white neighborhoods involved the police picking up African American youth whom they suspected but could not charge with crimes. The police dropped these youth off in locations where they knew they were likely to be beaten by local residents. A quarter-century later this practice again came to light when the Chicago Police Board fired several officers who left two African American youth in a former Back of the Yards white neighborhood, where they were assaulted by a gang of white youth (Chicago Sun-Times 1992:4). Such incidents persist as familiar topics of discussion in Chicago public schools (see Hagan, Hirschfield, and Shedd 2002:242-43).

\section{THE DATA AND THE VARIABLES}

The Chicago Consortium sample of ninth- and tenth-grade students parallels the previous account. The sample of schools was stratified by geographic location and income to be representative of the city. Ten of the 101 public high schools surveyed were eliminated from this analysis because less than 50 students in each of these schools participated. The response rate is 63 percent in the schools considered in this research, and our resulting sample contains 18,251 students without missing data on the variables considered. African American students make up nearly half of the sample, Latino/Hispanic youth form more than a third, white adolescents just over 10 percent, with 
Asian American and Native American students forming the remaining parts of the sample. At the extremes of racial and ethnic educational segregation, more than a quarter of the sampled schools are more than 85 percent African American, another 10 percent are more than 85 percent Latino/Hispanic, and less than 10 percent are more than 30 percent white. The five most highly integrated schools in our sample are from about one-third to less than one-half white, suggesting that only these few schools are even conceivably on the cusp of significant racial integration.

There is by now no doubt that the perception of criminal injustice is a scalable contemporary phenomenon (e.g., Hagan and Albonetti 1982; Wortley, Hagan, and Macmillan 1997; Brooks 2000). The Consortium survey included five measures of this perceived injustice in a four-point Likert scale ranging from strongly disagree to strongly agree responses to the following statements:

- People from my racial group are more likely to be unfairly stopped and questioned by the police.

- Police treat young people worse than old people.

- Police treat rich people better than poor people.

- Police treat people from my racial group worse than people from other racial groups.

- Police treat males worse than females.

The alpha reliability of this construct is .73 . The modal response category for all items is agreement, with the exceptions that the modal African American and Latino youth strongly agree that his or her racial group is more likely to be unfairly stopped and questioned by the police, while the modal white youth disagrees with this statement. With strong agreement assigned the highest value and the scale scores ranging from five to 20 , ninth- and tenth-grade Chicago youth score an average of 14.16 on this scale. The results also reflect the predicted racial/ethnic gradient of scores ranging from African American youth at 14.94, through Latino youth at 14.20 , to white youth at 12.74 , and Asian youth at 12.58. At the bivariate level, the difference in scores between African American and white $(\mathrm{t}=33.55)$ youth and African American and Latino $(\mathrm{t}=16.48)$ youth were highly significant $(p<.001){ }^{7}$

\footnotetext{
${ }^{7}$ When we varied the measurement of perceptions of criminal injustice by using only the two
}

Our comparative conflict perspective implies that racial and ethnic group membership has both individual- and school-contextual-level effects on perceptions of injustice. The full set of racial/ethnic, individual level dummy variables presented in Table 1 approximates the school population described earlier and includes African American (44.7\%), white (13\%), Asian (4.8\%), Latino/Hispanic (37.3\%), and American Indian/Alaskan Native (.002\%) categories. These categorizations are based on student selfreports of their group membership. The contextual-level comparative effect of school racial segregation is measured with the percent white student composition of the schools, which ranges from zero to 45 percent in Chicago. This percent white variable is a parsimonious exposure measure (Massey and Denton 1988; Orfield and Lee 2004:9-10) of segregation/integration that produces robust and replicable results for the African American and Latino subsamples that form the key groups for our next analysis. A percent white-squared term is included to capture the nonlinearity (see Jaccard, Turrisi, and Wan 1990:50) of the exposure effect indicated in the tipping point discussion earlier. Forty-one Chicago public high schools have no white students.

We have noted that socioeconomic status is also a potential parallel or rival factor in explaining perceptions of criminal injustice. The Consortium survey does not measure student family socioeconomic status directly, but mother's educational attainment is included, with dummy variables ranging from less than high school graduation $(26.1 \%)$ to college $(19 \%)$ and advanced (10.7\%) degrees. In addition, we have included a contextual measure of the percentage of the school whose families is below the poverty level. On the three-point scale summarizing the proportion of the school whose students are low income and qualify for reduced/free lunch programs, the average school ranks 2.52 , indicating that the majority of students in the average public school is from a poor family.

explicitly racial items or by including and excluding the rich/poor people measure, the results were substantively unchanged. See Tables A to D on our ASR online supplement (http://www.asanet.org/ journals/asr/2005/toc045.html). 
Table 1. Descriptive Statistics and Descriptions of Variables Used in the Analysis

\begin{tabular}{|c|c|c|c|}
\hline Variable & Mean & SD & Score Range \\
\hline \multicolumn{4}{|l|}{ Level One: Student Self-Report Data } \\
\hline Male & .458 & $(.498)$ & 0 to 1 \\
\hline Ninth grader & .561 & $(.496)$ & 0 to 1 \\
\hline Black $^{\mathrm{a}}$ & .447 & $(.497)$ & 0 to 1 \\
\hline White & .130 & $(.336)$ & 0 to 1 \\
\hline Asian & .048 & $(.213)$ & 0 to 1 \\
\hline Latino & .373 & $(.484)$ & 0 to 1 \\
\hline American Indian/Alaskan Native & .002 & $(.047)$ & 0 to 1 \\
\hline \multicolumn{4}{|l|}{ Mom's education } \\
\hline Less than high school graduate ${ }^{b}$ & .261 & $(.398)$ & 0 to 1 \\
\hline High school graduate & .235 & $(.424)$ & 0 to 1 \\
\hline Vocational/trade school education & .024 & $(.154)$ & 0 to 1 \\
\hline Some college & .183 & $(.386)$ & 0 to 1 \\
\hline College graduate & .190 & $(.392)$ & 0 to 1 \\
\hline Advanced degree & .107 & $(.309)$ & 0 to 1 \\
\hline Perception of injustice ${ }^{c}$ & 14.330 & $(3.087)$ & 5 to 20 \\
\hline Personal contact with police ${ }^{\mathrm{d}}$ & 6.345 & $(2.989)$ & 0 to 12 \\
\hline Personal trouble in school ${ }^{\mathrm{e}}$ & 7.265 & $(2.831)$ & 0 to 21 \\
\hline \multicolumn{4}{|l|}{ Level Two: School-reported Data } \\
\hline Racial composition: percent white & 12.885 & $(12.813)$ & 0 to 100 \\
\hline Racial composition: percent white squared & 330.190 & $(503.338)$ & 0 to 100 \\
\hline Average contact with police & 2.412 & $(1.422)$ & 0 to 9 \\
\hline Average trouble in school & 3.154 & $(1.947)$ & 0 to 13 \\
\hline \multicolumn{4}{|l|}{ Controls } \\
\hline Percentage of students in low-income families ${ }^{f}$ & 2.515 & $(.686)$ & 1 to 3 \\
\hline
\end{tabular}

a This measure uses student self-report data to construct dummy variables for race. This coding scheme assigns respondents to only one racial/ethnic group.

b Student's report on mother's highest education. This coding scheme assigns mother's educational attainment to one category.

${ }^{c}$ Five items were used to construct this ordinal measure of agreement with the following statements $(1=$ strongly disagree to 4 = strongly agree). Students were asked: "people from my racial group are more likely to be unfairly stopped and questioned by the police."; "police treat young people worse than old people."; "police treat rich people better than poor people."; "police treat people from my racial group worse than people from other racial groups.", "police treat males worse than females."

d Four items were used to construct this measure of frequency of contact with police (Recoded so that $0=$ never, $1=1-2$ times, $2=3-5$ times, 3 = more than 5 times). Students were asked: how many times in the last year have you: "been told off or told to move on by police?"; "been stopped and asked questions by the police?"; "been searched by the police?"; "been arrested by the police?."

e Seven items were used to construct this measure of frequency of trouble in school (Recoded so that $0=$ never, $1=1-2$ times, $2=3-5$ times, 3 = more than 5 times). Students were asked: how many times this school year have you: "gotten into trouble at school?"; "gotten into a physical fight with another student at school?"; "been sent to the office for getting in trouble?"; "been put on in-school suspension?"; "been suspended from school?"; "parents were contacted because of trouble?" and "parents came to the school because of trouble?"

f School administrative data measuring the percentage of students in the school who are low income and qualify for reduced/free lunch: $1=$ less than $50 \%$ low income; $2=50 \%-80 \%$ low income; $3=$ more than $80 \%$ low income.

As noted before, the comparative conflict perspective proposed in this paper must further consider the possibilities that African American and Latino youth are more involved in nonnormative behavior and are in more frequent conflict with the police. It is again important to acknowledge that this process may occur at both micro- and macro-levels, influencing not only the youth involved in non-normative behavior and in conflict with the law, but also those around them through vicarious peer and group processes. 
Our measure of non-normative behavior involves getting in trouble at school. This measure is based on responses to items scored on a seven-item scale asking how many times in the current school year have you "gotten into trouble at school?"; "gotten into a physical fight with another student at school?"; "been sent to the office for getting in trouble?"; "been put on in-school suspension?"; "been suspended from school?"; "parents were contacted because of trouble?"; and "parents came to school because of trouble?" African American youth score (7.8) significantly $(p<.001)$ higher than Latino $(7.00, \mathrm{t}=18.91)$ and white $(6.86, \mathrm{t}=14.71)$ students (Asian adolescents score 6.0) on this scale. The alpha reliability score for this construct is .81 . Mean school scores also were assigned to capture contextual effects of this school-based measure of student non-normative behavior.

Our further measure of personal contact with the police is based on answers to items asking how often in the past year youth have been "told off or told to move on by police"; "stopped and asked questions by the police"; "searched by the police"; and "been arrested by the police"? By the time the youth in our sample were in ninth and tenth grade, about half the African American, Latino, and White youth had been told off/told to move on and stopped and asked questions by the police, while a quarter to a third had been searched by police, and onetenth to one-fifth had been arrested. On a fourpoint scale ranging from never to more than five times, African American youth scored (6.6) significantly $(p<.001)$ higher than Latino $(6.27$, $\mathrm{t}=7.63)$ and white $(6.22, \mathrm{t}=6.01)$ students (Asian adolescents score 4.9) in police contact. The disproportionately low socioeconomic status of all public school students in Chicago likely explains the high levels of police contact across these groups. These relatively high levels of contact by ninth and tenth grade again indicate the appropriateness of this age group for our study. The alpha coefficient for this scaled combination of items is .85. Mean school scores of police contact were assigned to capture contextual effects of these encounters with the police.

To establish persuasively the theoretical viability of the comparative conflict perspective outlined in this paper, it is necessary to undertake a multilevel as well as multivariate analy- sis that assesses the micro- as well as macrolevel influences of the racial/ethnic/socioeconomic group memberships, non-normative behaviors and police contacts, and school contexts identified earlier. No previous study has considered this range of factors and levels of analysis with a large survey representative of a major American city such as Chicago.

\section{MULTILEVEL MODELS OF PERCEIVED CRIMINAL INJUSTICE}

The Chicago Consortium survey provides data that can be analyzed with a nested structure using appropriately adapted hierarchical linear models (HLM) that take into account the nonindependence of student responses within school contexts. HLM procedures (Bryk and Raudenbush 1992) are used to estimate within and between school equations simultaneously in the tables that follow. This approach joins the school and individual levels of analysis in a common framework that allows a multilevel, multivariate assessment of our comparative conflict perspective (see also Sampson, Raudenbush, and Earls 1997). Tables 2 through 5 present the results of our HLM estimations for the full sample and then separately assess nonadditive effects of variables such as police contacts within the subsamples of white, black, and Latino youth. We use confidence intervals and interaction terms (see Appendix) to explore whether variables such as police contacts (and other characteristics) have significantly different effects across these racial/ethnic groups.

The HLM estimations for the full sample in Table 2 indicate that with the full range of micro- and macro-level variables included in Model 4, about 15 percent of the former and two-thirds of the latter variation can be explained in respective individual and schoollevel perceptions of criminal injustice. Of course, there is greater variation to be explained in the former individual level than the latter school level of analysis, and these relative proportions of explained variance are consistent with earlier findings (see, e.g., Sampson and Bartusch 1998: Table 3). It is common for smaller levels of explained variation at the individual level to coincide with substantial levels of explained variation at higher levels, such as school context. 
Table 2. Impact of School Racial Composition on Youth Perception of Injustice

\begin{tabular}{|c|c|c|c|c|}
\hline Variable & Model 1 & Model 2 & Model 3 & Model 4 \\
\hline \multicolumn{5}{|l|}{ Level One: Student } \\
\hline Black & $\begin{array}{l}2.476 * * * \\
(.156)\end{array}$ & $\begin{array}{l}2.552 * * * \\
(.163)\end{array}$ & $\begin{array}{l}2.555^{* * * *} \\
(.169)\end{array}$ & $\begin{array}{l}2.465^{* * *} \\
(.168)\end{array}$ \\
\hline Asian & $\begin{array}{l}-.068 \\
(.234)\end{array}$ & $\begin{array}{l}-.071 \\
(.233)\end{array}$ & $\begin{array}{c}-.068 \\
(.230)\end{array}$ & $\begin{array}{l}.288 \\
(.204)\end{array}$ \\
\hline Latino & $\begin{array}{l}1.606^{* * * *} \\
(.138)\end{array}$ & $\begin{array}{l}1.627 * * * \\
(.139)\end{array}$ & $\begin{array}{l}1.627 * * * \\
(.138)\end{array}$ & $\begin{array}{l}1.671 * * * \\
(.140)\end{array}$ \\
\hline American Indian/Alaskan Native & $\begin{array}{l}1.535^{* *} \\
(.425)\end{array}$ & $\begin{array}{l}1.534 * * \\
(.428)\end{array}$ & $\begin{array}{l}1.484 * * \\
(.429)\end{array}$ & $\begin{array}{l}1.198 * * \\
(.366)\end{array}$ \\
\hline \multicolumn{5}{|l|}{ Controls } \\
\hline Male & - & - & $\begin{array}{l}.575 * * * \\
(.055)\end{array}$ & $\begin{array}{l}-.044 \\
(.055)\end{array}$ \\
\hline Ninth grader & - & - & $\begin{array}{l}-.193 * * * \\
(.048)\end{array}$ & $\begin{array}{l}-.201 * * * \\
(.048)\end{array}$ \\
\hline \multicolumn{5}{|l|}{ Mom's education } \\
\hline High school graduate & - & - & $\begin{array}{l}-.121 \\
(.069)\end{array}$ & $\begin{array}{l}-.072 \\
(.063)\end{array}$ \\
\hline Vocational/trade school & - & - & $\begin{array}{l}-.075 \\
(.144)\end{array}$ & $\begin{array}{l}-.143 \\
(.142)\end{array}$ \\
\hline Some college & - & - & $\begin{array}{l}.129 \\
(.076)\end{array}$ & $\begin{array}{l}.163^{*} \\
(.076)\end{array}$ \\
\hline College graduate & - & - & $\begin{array}{l}-.064 \\
(.077)\end{array}$ & $\begin{array}{l}.005 \\
(.076)\end{array}$ \\
\hline Advanced degree & - & - & $\begin{array}{l}-.019 \\
(.095)\end{array}$ & $\begin{array}{l}.012 \\
(.094)\end{array}$ \\
\hline Personal contact with police & - & - & - & $\begin{array}{l}.306^{* * *} \\
(.012)\end{array}$ \\
\hline Personal trouble in school & - & - & - & $\begin{array}{l}.013 \\
(.009)\end{array}$ \\
\hline \multicolumn{5}{|l|}{ Level Two: School } \\
\hline Percent white & - & $\begin{array}{l}.046^{* * *} \\
(.012)\end{array}$ & $\begin{array}{l}.044 * * \\
(.013)\end{array}$ & $\begin{array}{l}.036 * * \\
(.013)\end{array}$ \\
\hline Percent white squared & - & $\begin{array}{l}-.0008 * * \\
(.0003)\end{array}$ & $\begin{array}{c}-.0008^{*} \\
(.0003)\end{array}$ & $\begin{array}{c}-.0007^{*} \\
(.0003)\end{array}$ \\
\hline \multicolumn{5}{|l|}{ Controls } \\
\hline School $50 \%-80 \%$ low income & - & - & $\begin{array}{l}.071 \\
(.139)\end{array}$ & $\begin{array}{l}.127 \\
(.139)\end{array}$ \\
\hline School $80 \%-95 \%$ low income & - & - & $\begin{array}{l}-.064 \\
(.115)\end{array}$ & $\begin{array}{l}-.055 \\
(.130)\end{array}$ \\
\hline Average student contact with police & - & - & - & $\begin{array}{l}-.210 \\
(.111)\end{array}$ \\
\hline Average student trouble in school & - & - & - & $\begin{array}{c}-.128 * \\
(.058)\end{array}$ \\
\hline Constant & $\begin{array}{c}12.472 * * * \\
(.135)\end{array}$ & $\begin{array}{c}12.208^{* * *} \\
(.173)\end{array}$ & $\begin{array}{c}12.120 * * * \\
(.215)\end{array}$ & $\begin{array}{c}12.565^{* * * *} \\
(.272)\end{array}$ \\
\hline Level One Variance & 8.718 & 8.718 & 8.626 & 7.900 \\
\hline Explained Variation & .057 & .057 & .067 & .146 \\
\hline Level Two Variance & .149 & .100 & .097 & .090 \\
\hline Explained Variation & .429 & .617 & .628 & .655 \\
\hline Level One N & 18251 & 18251 & 18251 & 18251 \\
\hline Level Two N & 91 & 91 & 91 & 91 \\
\hline
\end{tabular}

Note: Data shown as hierarchical linear model (HLM) regressions; standard errors are shown in parentheses. Reference categories: race $=$ white; mom's education $=$ less than high school; school percent of low income students $=$ less than $50 \%$.

$* p<.05 ; * * p<.01 ; * * * p<.001$ (two-tailed). 
Table 3. Impact of School Racial Composition on White Youth Perception of Injustice

\begin{tabular}{|c|c|c|c|}
\hline Variable & Model 1 & Model 2 & Model 3 \\
\hline \multicolumn{4}{|l|}{ Level One: Student } \\
\hline \multicolumn{4}{|l|}{ Controls } \\
\hline Male & - & $\begin{array}{l}.674 * * * \\
(.121)\end{array}$ & $\begin{array}{c}.152 \\
(.114)\end{array}$ \\
\hline Ninth grader & - & $\begin{array}{c}-.139 \\
(.178)\end{array}$ & $\begin{array}{c}-.118 \\
(.167)\end{array}$ \\
\hline \multicolumn{4}{|l|}{ Mom's education } \\
\hline High school graduate & - & $\begin{array}{c}-.338 \\
(.188)\end{array}$ & $\begin{array}{c}-.085 \\
(.166)\end{array}$ \\
\hline Vocational/trade school & - & $\begin{array}{l}-.208 \\
(.293)\end{array}$ & $\begin{array}{l}.154 \\
(.275)\end{array}$ \\
\hline Some college & - & $\begin{array}{c}-.351 \\
(.252)\end{array}$ & $\begin{array}{l}-.110 \\
(.217)\end{array}$ \\
\hline College graduate & - & $\begin{array}{l}-.343 \\
(.179)\end{array}$ & $\begin{array}{l}-.047 \\
(.149)\end{array}$ \\
\hline Advanced degree & - & $\begin{array}{l}-.426 \\
(.246)\end{array}$ & $\begin{array}{l}-.022 \\
(.209)\end{array}$ \\
\hline Personal contact with police & - & - & $\begin{array}{l}.339 * * * \\
(.033)\end{array}$ \\
\hline Personal trouble in school & - & - & $\begin{array}{l}.060^{* *} \\
(.023)\end{array}$ \\
\hline \multicolumn{4}{|l|}{ Level Two: School } \\
\hline Racial composition: percent white & $\begin{array}{l}-.015 \\
(.015)\end{array}$ & $\begin{array}{c}-.011 \\
(.020)\end{array}$ & $\begin{array}{c}-.0007 \\
(.019)\end{array}$ \\
\hline Racial composition: percent white squared & $\begin{array}{c}.00004 \\
(.0003)\end{array}$ & $\begin{array}{l}-.000004 \\
(.0003)\end{array}$ & $\begin{array}{c}-.00008 \\
(.0003)\end{array}$ \\
\hline \multicolumn{4}{|l|}{ Controls } \\
\hline School $50 \%-80 \%$ low income & - & $\begin{array}{l}.338 \\
(.265)\end{array}$ & $\begin{array}{l}.255 \\
(.259)\end{array}$ \\
\hline School $80 \%-95 \%$ low income & - & $\begin{array}{l}.199 \\
(.235)\end{array}$ & $\begin{array}{l}.104 \\
(.243)\end{array}$ \\
\hline Average student contact with police & - & - & $\begin{array}{l}-.224 \\
(.141)\end{array}$ \\
\hline Average student trouble in school & - & - & $\begin{array}{l}.074 \\
(.141)\end{array}$ \\
\hline Constant & $\begin{array}{c}13.108 * * * \\
(.250)\end{array}$ & $\begin{array}{c}12.882 * * * \\
(.433)\end{array}$ & $\begin{array}{c}12.170 * * * \\
(.509)\end{array}$ \\
\hline Level One Variance & 7.875 & 7.765 & 6.694 \\
\hline Explained Variation & -.0005 & .013 & .150 \\
\hline Level Two Variance & .135 & .129 & .130 \\
\hline Explained Variation & .167 & .204 & .198 \\
\hline Level One N & 2371 & 2371 & 2371 \\
\hline Level Two N & 45 & 45 & 45 \\
\hline
\end{tabular}

Note: Data shown as hierarchical linear model (HLM) regressions; standard errors are shown in parentheses. Reference categories: race $=$ white; mom's education $=$ less than high school; school percent of low income students $=$ less than $50 \%$.

$* p<.05 ; * * p<.01 ; * * * p<.001$ (two-tailed).

Model 1 in Table 2 contains the four racial/ethnic categories of adolescents who can be compared with the omitted category of white youth in our analysis of the Chicago school data. While Asian youth are not significantly different in their perceptions of criminal injustice than whites in this estimation, all the remaining groups are significantly different $(p<.01)$, with the expected gradient of African American youth (2.48) perceiving more injustice relative to whites than do Latinos (1.61), and the latter scoring just higher than Native American youth 
(1.54). The relative size and significance of the additive African American and Latino main effects provide preliminary support for our first two comparative conflict hypotheses and the earlier report of mean group differences. The non-overlapping .95 confidence intervals for the African American (2.17/2.78) and Latino $(1.34 / 1.88)$ youth coefficients confirm not only that both of these groups score higher than whites, but that there is a significant gradient between these effects. The Native American finding also is of obvious potential interest, although we do not pursue this further here because of the limited size of this group in our Chicago sample.

Model 2 in Table 2 introduces our consideration of school-level variables with our percent white measure of school integration, and with a percent white-squared measure also included to capture the possibility that the effect of student racial composition changes as it moves toward a potential tipping point. Both of these effects are significant $(p<.01)$ in Model 2, with a positive effect of percent white (.05) indicating that perceptions of criminal injustice increase with the integration of whites into the Chicago public schools, and with a further and smaller negative effect of percent whitesquared (-.0008) indicating that this trend ultimately begins to decline. No further change of direction was indicated when we added a cubed term to the HLM equation. These school-level effects lend preliminary support for our fourth and sixth hypotheses about the sense of relative deprivation for minorities that may at first increase and then ultimately abate with integration of white students into public schools.

Models 3 and 4 add into the analysis controls for the parallel and rival influences of individual and school-level variables. At the individual level in Model 3 of Table 2, we see that males perceive significantly more criminal injustice than females $(.58, p<.001)$, and that ninth graders perceive less than tenth graders (-.19, $p<.001)$. There is no significant evidence at the school level in Model 3 that perceptions of injustice are greater in poorer than more affluent schools. The hypothesized individual and school-level racial/ethnic effects remain significant in Model 3, net of all other included variables.

The racial/ethnic effects further persist in their significance when the individual and school-level measures of contact with police and trouble in school are introduced in Model 4. The most salient of these variables is individual-level personal contact with the police $(.31, p<.001)$, which notably increases perceptions of criminal injustice. The school-level effects of average student police contact and trouble in school are negative and the latter is statistically significant in this model $(p<.05)$, but these effects do not persist in following tables and therefore are not discussed further here. Overall, the results in Table 2 provide further support for our first two hypotheses about the additive gradient in the micro-level African American and Latino adolescents' perceptions of criminal injustice relative to those of whites, as well as preliminary support for the fourth and sixth hypotheses of macro-level effects of school segregation on these perceptions. Only the school-level effect of percent white-squared decreases in statistical significance in Model 4, and this effect is still significant at the .05 level. To assess more thoroughly, however, our third hypothesis about the role of police contacts for the micro-level gradient in race/ethnicity effects and our fifth hypothesis about a macro-level racial/ethnic gradient in the effects of school segregation, we next consider the likelihood of nonadditive effects within the racial and ethnic subsamples. The gradient in the values of the intercepts in later tables suggest that groupbased racial differences in perceptions retain their main effects; however, there is evidence of nonadditive influences as well, as we see next.

We initially modified the equations estimated in Table 2 by adding interaction terms and alternating the omitted racial reference group. The results, presented in Appendix Tables Al and $\mathrm{A} 2$, indicate that a number of significant interactions occur by race. These interactions can be better understood by examining our data within the white, African American, and Latino subsamples. Table 3 provides a benchmark by presenting HLM estimations for the subsample of white youths that can be compared with subsequent estimations for African American and Latino subsamples in following tables. We highlight the school effects of segregation on perceptions of criminal injustice by estimating these effects alone in Model 1 of the following three tables. As implied by a comparative conflict perspective, the percent white and percent white-squared variables have no significant 
effects when estimated in the white subsample in Table 3. Being male still has a pronounced effect on the perception of criminal injustice among white youth $(.67, p<.001)$ in Model 2. Meanwhile, both the individual-level contact with police $(.34, p<.001)$ and trouble in school $(.06, p<.01)$ variables added in Model 3 of Table 3 lead to greater perceived injustice, while neither of the school-level police contact nor school trouble variables have significant effects, and the school-level low-income variables are nonsignificant as well. The salient causes of perceived criminal injustice among white youth are the individual-level police contact and school-trouble variables, which reduce the only remaining notable effect of being male to nonsignificance in Model 3.

Table 4 presents a more complex picture for African American youth. While the percent white and percent white-squared exposure measures were unsurprisingly nonsignificant for white youth, they are both notably significant for African American youth in Model 1 of Table 4. The combination of these positive $(.07, p<$ $.001)$ and negative $(-.002, p<.01)$ effects respectively provide support for our fourth hypothesis that the comparative effect of being African American increases with the proportion of white students in schools - until at some point this influence peaks and then begins to decline, as anticipated in our sixth tipping point hypothesis. These effects remain robust through the addition of remaining variables in Models 2 and 3.

The final Model 3 results confirm that for African American youth, perceptions of criminal injustice increase among the older children (i.e., the ninth grader coefficient is $-.20, p<.01$ ) of mothers with some college education $(.44, p$ $<.001)$ and who have had contact with the police $(.26, p<.001)$. Note that the latter police contact effect, while it is still highly significant, is somewhat reduced from the full sample and the white subsample, further illustrating the "experience of the expected" that a greater familiarity with police contacts may produce. It is notable that in this third Model, with personal contact with the police included, the effect of being male actually becomes significantly negative $(-.22, p<.01)$. The latter effects do little to diminish the school-level influence of the school segregation variables, percent white $(.07$, $p<.001)$ and percent white-squared (-.001, $p$ $<.01$ ), which persist in their significance.

Table 5 presents a somewhat different picture for Latino youth. The percent white $(.04, p<.05)$ measure is again significant for Latino youth in Model 1 of Table 5. The effects of percent white and percent white squared are modestly increased and both are statistically significant $(p<.05)$ with the addition of remaining variables in Model 3. These slightly weaker effects for Latino compared to African American youth are in the predicted direction of our fifth hypothesis that extends the micro-level gradient to the macro-level, although some overlap in confidence levels for these percent white coefficients fails to provide full statistical support for this predicted gradient. ${ }^{8}$ So there is only partial statistical support for the fifth macro-level gradient hypothesis.

The final Model 3 results in Table 5 indicate that for Latino youth, perceptions of criminal injustice increase among older children (i.e., the ninth grader coefficient is $-.26, p<.001)$ of mothers without college education (i.e., the mother with some college coefficient is $-.21, p$ $<.05)$ and who have had contact with the police $(.36, p<.001)$. The opposite effects of some college education among mothers of Latino and African American youth (i.e., decreasing these perceptions among Latinos and increasing them among African Americans), is further confirmed by non-overlapping confidence intervals at the .95 level (-.383/.027 and .258/.630). The police contact variable is significant and more salient in its effect among Latino than African American youth, with non-overlapping .95 confidence intervals $(.337 / .389 ; .232 / .288)$. This finding indicates that Latino youth are more sensitive to (and their perceptions therefore are more negatively influenced by) police contacts than are African American youth. White students are more like Latino than black students in their sensitivity to police contacts $(.339, p<.001)$, which likely reflects the reduced experience of both of the former groups with these contacts. Later we return to the argument that it is the

\footnotetext{
${ }^{8}$ The confidence intervals are nearly non-overlapping for the percent white variable among white youth (-.038/.036) and African American youth (.033/.099), with Latino youth, as expected, in between (.001/.079).
} 
Table 4. Impact of School Racial Composition on Black Youth Perception of Injustice

\begin{tabular}{|c|c|c|c|}
\hline Variable & Model 1 & Model 2 & Model 3 \\
\hline \multicolumn{4}{|l|}{ Level One: Student } \\
\hline \multicolumn{4}{|l|}{ Controls } \\
\hline Male & - & $\begin{array}{l}.372 * * * \\
(.078)\end{array}$ & $\begin{array}{l}-.219 * * \\
(.080)\end{array}$ \\
\hline Ninth grader & - & $\begin{array}{c}-.213 * * \\
(.077)\end{array}$ & $\begin{array}{c}-.197 * * \\
(.071)\end{array}$ \\
\hline \multicolumn{4}{|l|}{ Mom's education } \\
\hline High school graduate & - & $\begin{array}{c}-.103 \\
(.107)\end{array}$ & $\begin{array}{c}-.019 \\
(.100)\end{array}$ \\
\hline Vocational/trade school & - & $\begin{array}{l}-.172 \\
(.235)\end{array}$ & $\begin{array}{l}-.212 \\
(.234)\end{array}$ \\
\hline Some college & - & $\begin{array}{l}.350 * * * \\
(.092)\end{array}$ & $\begin{array}{l}.444 * * * \\
(.093)\end{array}$ \\
\hline College graduate & - & $\begin{array}{c}.051 \\
(.136)\end{array}$ & $\begin{array}{c}.164 \\
(.131)\end{array}$ \\
\hline Advanced degree & - & $\begin{array}{c}.084 \\
(.137)\end{array}$ & $\begin{array}{l}.152 \\
(.130)\end{array}$ \\
\hline Personal contact with police & - & - & $\begin{array}{l}.260 * * * \\
(.014)\end{array}$ \\
\hline Personal trouble in school & - & - & $\begin{array}{l}.000 \\
(.013)\end{array}$ \\
\hline \multicolumn{4}{|l|}{ Level Two: School } \\
\hline Racial composition: percent white & $\begin{array}{l}.074 * * * \\
(.016)\end{array}$ & $\begin{array}{l}.068^{* * *} \\
(.016)\end{array}$ & $\begin{array}{l}.066^{* * *} \\
(.017)\end{array}$ \\
\hline Racial composition: percent white squared & $\begin{array}{c}-.0015^{* *} \\
(.0004)\end{array}$ & $\begin{array}{c}-.0014 * * \\
(.0004)\end{array}$ & $\begin{array}{c}-.0014 * * \\
(.0004)\end{array}$ \\
\hline \multicolumn{4}{|l|}{ Controls } \\
\hline School $50-80 \%$ low income & - & $\begin{array}{c}-.069 \\
(.191)\end{array}$ & $\begin{array}{c}-.058 \\
(.179)\end{array}$ \\
\hline School $80-95 \%$ low income & - & $\begin{array}{c}-.148 \\
(.155)\end{array}$ & $\begin{array}{l}-.153 \\
(.175)\end{array}$ \\
\hline Average student contact with police & - & - & $\begin{array}{l}-.169 \\
(.124)\end{array}$ \\
\hline Average student trouble in school & - & - & $\begin{array}{c}-.089 \\
(.059)\end{array}$ \\
\hline Constant & $\begin{array}{c}14.669 * * * \\
(.085)\end{array}$ & $\begin{array}{c}14.697 * * * \\
(.178)\end{array}$ & $\begin{array}{c}14.946^{* * * *} \\
(.272)\end{array}$ \\
\hline Level One Variance & 9.391 & 9.334 & 8.827 \\
\hline Explained Variation & .000 & .006 & .060 \\
\hline Level Two Variance & .142 & .132 & .134 \\
\hline Explained Variation & .401 & .443 & .435 \\
\hline Level One N & 8151 & 8151 & 8151 \\
\hline Level Two N & 80 & 80 & 80 \\
\hline
\end{tabular}

Note: Data shown as hierarchical linear model (HLM) regressions; standard errors are shown in parentheses. Reference categories: race $=$ white; mom's education $=$ less than high school; school percent of low income students $=$ less than $50 \%$.

$* p<.05 ; * * p<.01 ; * * * p<.001$ (two-tailed).

familiarity of the police threat and the "experience of the expected" that helps to explain the lower police contact effect on perceptions of African American youth. Meanwhile, the police contact variable removes but does not reverse the gender effect among Latinos (as we saw it do earlier with African American youth). Interestingly, while personal trouble at school significantly increases perceived criminal injustice among whites, it is nonsignificant for both Latinos and African American adolescents. 
Table 5. Impact of School Racial Composition on Latino Youth Perception of Injustice

\begin{tabular}{|c|c|c|c|}
\hline Variable & Model 1 & Model 2 & Model 3 \\
\hline \multicolumn{4}{|l|}{ Level One: Student } \\
\hline \multicolumn{4}{|l|}{ Controls } \\
\hline Male & - & $\begin{array}{l}.709 * * * \\
(.090)\end{array}$ & $\begin{array}{l}-.011 \\
(.090)\end{array}$ \\
\hline Ninth grader & - & $\begin{array}{l}-.228^{* *} \\
(.068)\end{array}$ & $\begin{array}{l}-.262 * * * \\
(.070)\end{array}$ \\
\hline \multicolumn{4}{|l|}{ Mom's education } \\
\hline High school graduate & - & $\begin{array}{c}-.065 \\
(.102)\end{array}$ & $\begin{array}{l}-.068 \\
(.089)\end{array}$ \\
\hline Vocational/trade school & - & $\begin{array}{c}.081 \\
(.221)\end{array}$ & $\begin{array}{l}-.083 \\
(.203)\end{array}$ \\
\hline Some college & - & $\begin{array}{l}-.090 \\
(.095)\end{array}$ & $\begin{array}{l}-.205^{*} \\
(.089)\end{array}$ \\
\hline College graduate & - & $\begin{array}{l}-.061 \\
(.104)\end{array}$ & $\begin{array}{l}-.095 \\
(.091)\end{array}$ \\
\hline Advanced degree & - & $\begin{array}{l}.100 \\
(.148)\end{array}$ & $\begin{array}{l}-.062 \\
(.151)\end{array}$ \\
\hline Personal contact with police & - & - & $\begin{array}{l}.363^{* * * *} \\
(.013)\end{array}$ \\
\hline Personal trouble in school & - & - & $\begin{array}{l}.002 \\
(.011)\end{array}$ \\
\hline \multicolumn{4}{|l|}{ Level Two: School } \\
\hline Racial composition: percent white & $\begin{array}{l}.039^{*} \\
(.019)\end{array}$ & $\begin{array}{l}.038 \\
(.021)\end{array}$ & $\begin{array}{l}.044^{*} \\
(.018)\end{array}$ \\
\hline Racial composition: percent white squared & $\begin{array}{c}-.00082 \\
(.00043)\end{array}$ & $\begin{array}{c}-.00083 \\
(.00046)\end{array}$ & $\begin{array}{c}-.00099 * \\
(.00041)\end{array}$ \\
\hline \multicolumn{4}{|l|}{ Controls } \\
\hline School $50-80 \%$ low income & - & $\begin{array}{l}-.093 \\
(.213)\end{array}$ & $\begin{array}{l}-.272 \\
(.200)\end{array}$ \\
\hline School $80-95 \%$ low income & - & $\begin{array}{l}-.132 \\
(.218)\end{array}$ & $\begin{array}{l}-.250 \\
(.169)\end{array}$ \\
\hline Average student contact with police & - & - & $\begin{array}{l}.093 \\
(.135)\end{array}$ \\
\hline Average student trouble in school & - & - & $\begin{array}{l}-.121 \\
(.087)\end{array}$ \\
\hline Constant & $\begin{array}{c}13.964 * * * \\
(.106)\end{array}$ & $\begin{array}{c}13.909 * * * \\
(.270)\end{array}$ & $\begin{array}{c}13.669 * * * \\
(.378)\end{array}$ \\
\hline Level One Variance & 8.223 & 8.093 & 7.124 \\
\hline Explained Variation & .000 & .016 & .134 \\
\hline Level Two Variance & .106 & .119 & .070 \\
\hline Explained Variation & .086 & -.026 & .400 \\
\hline Level One N & 6815 & 6815 & 6815 \\
\hline Level Two N & 71 & 71 & 71 \\
\hline
\end{tabular}

Note: Data shown as hierarchical linear model (HLM) regressions; standard errors are shown in parentheses. Reference categories: race $=$ white; mom's education = less than high school; school percent of low income students $=$ less than $50 \%$.

$* p<.05 ; * * p<.01 ; * * * p<.001$ (two-tailed).

To get a fuller picture of the effects on youth perceptions of police contacts and the integration of whites into Chicago schools, we present in Figure 1 a graphical representation of each group's scores calculated at zero, 15, 30, and 45 percent white intervals. This figure further dis- plays the nonadditive impact of structural differences in effects of police contacts among the racial/ethnic groups while holding compositional differences in these contacts more fully constant. This is important because while as we have noted African American youth have 


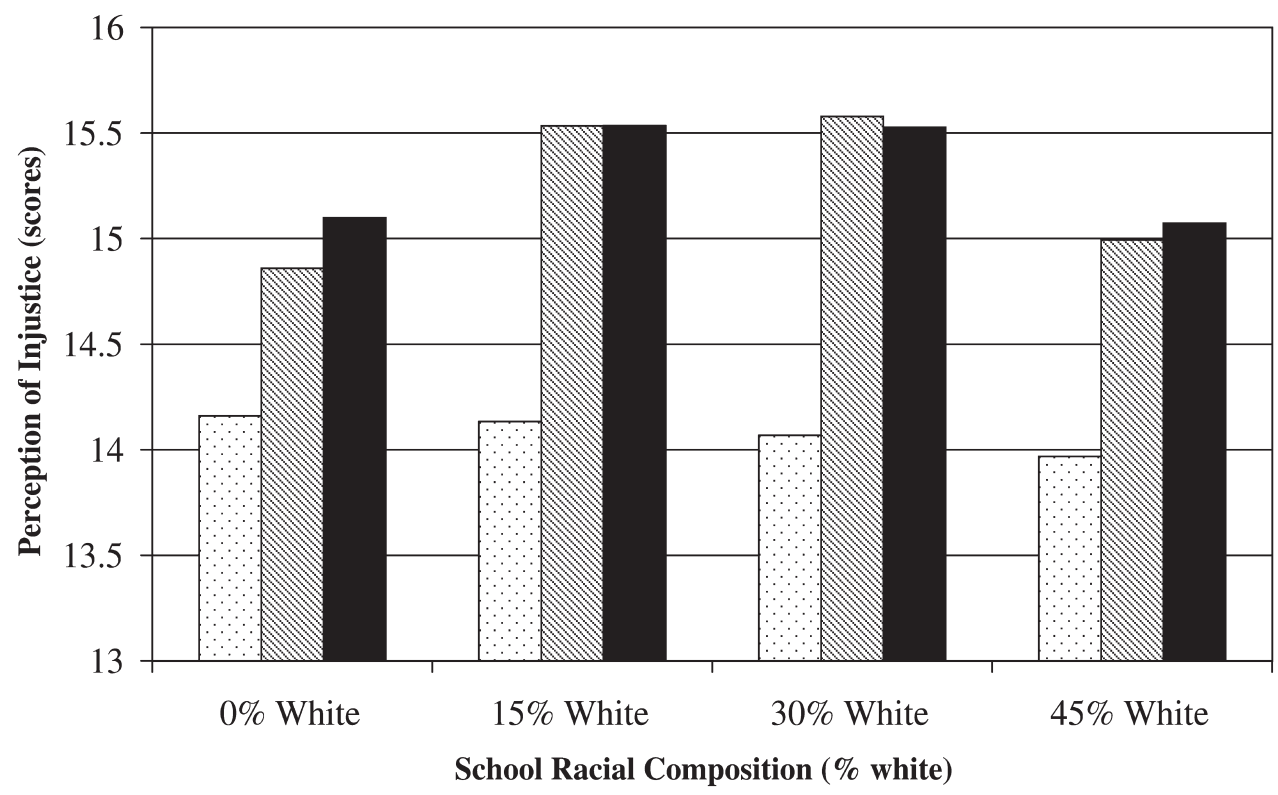

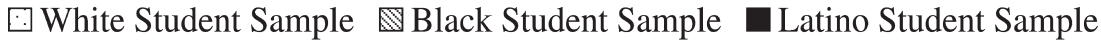

Figure 1. Impact of School Racial Composition on Perception of Injustice by Racial/Ethnic Group

Note: The "average student" is calculated as follows: gender $=$ male; grade $=10$ th; mom's education $=$ less than high school; personal contact with police = one standard deviation above the mean (5.336); personal trouble in school $=$ one standard deviation above the mean $(6.796)$; school percent low income $=80 \%-95 \%$; average student contact with police $=$ one standard deviation above the mean (3.835); average trouble in school $=$ one standard deviation above the mean (5.101).

more contact with the police, Latino youths' perceptions of injustice are more strongly affected by their police contacts (i.e., see again Model 3 in Tables 4 and 5). We have argued that it is the familiar "experience of the expected" that reduces the police contact effect among African American youth. This difference makes it noteworthy to consider structural and compositional variation of police contacts in assessing our third hypothesis, namely, that responses to police contacts may be an important factor in producing similarities as well as differences in Latino and African American perceptions of criminal injustice. We examine the latter possibilities by using the full prediction equations in Model 3 of Tables 3 through 5. In our use of these prediction equations, we initially allow the structural coefficients to vary among groups, while holding compositional differences constant by substituting the overall sample means into the prediction equations.

Thus in Figure 1 we allowed the structural effects to vary by using the group-specific coef- ficients, and we held the compositional differences among groups constant by creating a new generic respondent: a male, in tenth grade, whose mother has less than a high school education, whose personal and school contacts with the police and trouble in school are set one standard deviation above the overall sample means, and whose school percent low income is 80 to 95 percent. More specifically, in the calculations for Figure 1 we allowed the nonadditive difference in structural coefficients for the effects of police contacts among the African American (.260) and Latino (.363) youth to vary, while we used the overall sample mean of police contacts (5.336) to hold compositional differences constant. When for comparative purposes we further allowed the compositional differences in mean police contacts for African American (5.647) and Latino (5.237) youth to vary, the African American calculation increased only slightly and the Latino calculation was nearly unchanged. The implication is that it is the greater structural sensitivity of Latino youth to 
police contacts, rather than the higher compositional vulnerability of African American youth to police contacts, that is more consequential in driving the respective perceptions of criminal injustice.

The findings presented in Figure 1 suggest that the heightened structural sensitivity of Latino youth to contacts with police can result in their predicted perceptions of injustice becoming similar and initially even surpassing those of African American youth. At zero percent white, we now see that the Latino youth are actually even more sensitive to perceived criminal injustice than the African American youth. At 15 and 30 percent white, we see a leveling off of the peak scores of the Latino and African American perceptions at about 15.5 on the perceived criminal injustice scale. That is, as the estimation moves to schools with some white representation, the Latino and African American scores coincide in the middle part of the figure. This convergence occurs because, as we saw earlier, African Americans are more sensitive to racial integration than Latinos. Finally, at 45 percent white, we see the faster decline of African American perceptions and the slightly more modest decline in Latino perceptions. In these latter handful of schools that begin to provide more than a token level of white student integration, the Latino and African American scores decline by about a half point to approximately 15. The results in Figure 1 therefore indicate that, as anticipated in hypothesis three, the stronger reactions of Latino youth to police contacts can offset the lower frequency of their contacts with police and contribute to a convergence in African American and Latino perceptions of criminal injustice. Meanwhile, the Latino and African American scores are still nearly a point higher than the white student scores. Both police contacts and integration of schools have notable impacts on African American and Latino youths' perceptions of criminal injustice, while the police contact effect is especially notable for Latinos, and the segregation/integration effect is somewhat more notable for African Americans.

We also carried out a final sensitivity analysis of our finding (i.e., with the school measure of percent white-squared) that integration of whites at levels that begin to approach parity result in some abatement in perceptions of criminal injustice for Latinos and African Americans.
This analysis proceeded by reestimating the final structural equations for African Americans and Latinos after removing schools from the sample, one at a time, in the order of their percent white population. ${ }^{9}$ This analysis reveals that for Latino youth it is the top five schools in percent white population, and for African American youth the top four schools in percent white population, that account for the abatement in perceived injustice. It is notable that this effect, with this unusual opportunity for replication across groups, holds separately and similarly for Latino and African American youth in the Chicago schools that range from about one third to 45 percent white.

\section{THE COGNITIVE LANDSCAPES OF CRIMINAL INJUSTICE}

Sampson and Bartusch (1998:800) suggest the metaphor of "cognitive landscapes" to describe the demographic and ecological structuring of troubled American settings where "crime and deviance are more or less expected and institutions of criminal justice are mistrusted." The contours of these contemporary American landscapes are becoming clearer as surveys attend to the multiple groupings and age-graded settings in which citizens and law enforcement officials come into contact. We have chosen to focus on young persons in secondary schools because perceptions of justice and political institutions are formed at relatively young ages and remain persistent through adulthood. Our findings reveal that while perceptions of criminal justice become more negative in middle adolescence among Latino and African American youth, this is not apparent among white youth of the same ages in our sample.

Mental maps of distrust have both generic and differentiated features, including on the one hand shared skepticism of a range of governmental institutions in addition to agencies of criminal justice, and on the other hand groupspecific perceptions varying along dimensions with differences and similarities that a comparative conflict theory can identify and help to explain. We have argued that the development

9 The results of this analysis are summarized in Table E on our ASR online supplement (http://www. asanet.org/journals/asr/2005/toc045.html). 
of a comparative conflict perspective on perceived criminal injustice requires a nuanced understanding of the relative positions of subordinate and dominate groups who form relative and collective points of reference for one another.

In large American cities where Latino and African Americans live, work, and attend school in varying degrees of proximity to one another as well as with whites, there is an implicit racial gradient of relative subordination. A comparative conflict theory emphasizes that in the aggregate, African American youth are at heightened comparative risk of justice system surveillance, apprehension, and mistreatment relative to Latino Americans, who in turn are at greater risk than whites. These differential risks probably lead black youth collectively to perceive more criminal injustice than Latino youth, who in turn perceive more criminal injustice that their white counterparts. Yet we know little of the mechanisms by which these comparative assessments are formed and of how the familiarity with police harassment among African American urban youth influences their perceptions.

We have found evidence that white and Latino as well as black youth are sensitive to elevated levels of police contact, as reflected by the direct effect of these contacts on their perceptions of criminal injustice. While African American youth are in relative terms exposed more frequently to police contacts, however, white as well as Latino youth may actually be more sensitive to police contacts when they are subjected to them. Since Latino youth have a higher base level of perceived criminal injustice than white youth, this sensitivity is especially consequential for them. We have shown that when perceptions of criminal injustice are estimated with differences in responses to police contacts that are allowed to vary across groups, Latino youth appear much more incredulous than white youth of the justice system, and are more comparable to black youth. That is, when we allow structural differences between the effects of police contacts on black and Latino youth to vary, their perceptions of criminal injustice appear more similar, while both of these groups still perceive more criminal injustice than white youth. Latino youth, who are less familiar with police harassment than African American youth, may fear that their contacts with the police place them in a similar risk status as black youth. In this important sense, there is commonality as well as difference in African American and Latino experiences of criminal injustice.

The comparative perceptions of Latino and African American youth are further shaped by the frames of reference that result from their daily experiences in school. As scholars such as Orlando Patterson and Richard Brooks note, segregated residential and educational settings restrict the perceptions of ghettoized African American and Latino youth, while more integrated institutional experiences increase contacts and comparisons across groups, intensifying their relative sensitivity and placing them on heightened alert for differential treatment. As this comparative frame of reference expands to include an awareness of the relative and group-specific risks of exposure to mistreatment, members of groups who feel uniquely targeted by the police and courts appear more sensitive to the perception of injustice. In such contexts, the familiar "experience of the expected" can be newly perceived as outrageous. Patterson calls this the outrage of liberation. We found this pattern in Chicago public high schools among both Latino and African American youth who become more sensitive to perceptions of injustice as they are exposed to low but increasing percentages of white students in their schools.

Yet there is also a limited linearity of this effect of white representation on the comparative experience of school environments. That is, there appear to be potential minimums and maximums to the experience of relative deprivation and subordination in educational settings. Chicago public high schools have become more rather than less segregated since the early 1980s, and a large proportion of these schools have very few white students. We found that as the proportion of white students at first increases, so too do perceptions of relative criminal injustice. Patterson further refers to this as the ordeal of integration. Yet, as Patterson's work also implies, in the four or five Chicago public high schools where the proportion of white students ranges from about one-third to one-half, the gaps in minority perceptions of criminal injustice, for African American and Latino youth relative to whites, begin to decline. The replication of the parallel finding of the increase and abatement of perceptions of injustice is striking in its 
appearance in the separate subsamples of African American and Latino youth.

It is possible if not probable that there is a macro- as well as micro-level racial gradient to the rise and fall of African and Latino American perceptions of criminal injustice. That is, we have found not only persuasive evidence at the micro-level that African American youth perceive higher levels of criminal injustice than Latino youth, and that the perceptions of both groups rise and then decline in association with the proportion of white students in their schools, but also suggestive further evidence (in direction and size if not statistical significance) that with increasing representation of whites in public schools, the elevation and reduction in perceived injustice relative to whites is more intensely felt by African American than Latino youth.

In any case, regardless of the statistical significance of the latter differential sensitivity, there is compelling evidence that the perceptions of criminal injustice among both African and Latino American youth are at first intensified and then modestly improved by the increasing proportionate representation of white students in their schools. For policy purposes, it is probably this similarity that is most significant, for these macro-level contextual effects imply that integration of whites into public schools must reach critical levels that approach parity before benefits are realized among both African American and Latino youth. Unfortunately, this finding comes at a time when contemporary efforts to advance the integration of American schools in general, and Chicago schools in particular, are in decline.

Meanwhile, it is a possible further irony of this paper that efforts to make city schools safer through increased deployment of the police may have the unintended consequence of alienating the students who are ostensibly being protected. This makes it important to consider ways that police behavior can be modified to reduce some of the hostility that it generates among minority youth. Vrij and Winkel (1992) observe in their research that when police adopt a more respectful attitude in interactions with African American youth, potential conflict can be diminished. Our findings similarly suggest the potential benefits of such possibilities.

The results of our research represent only one American city, yet this city is large and the sampling of its public schools is comprehensive, and we believe that there are added reasons to take these findings seriously. The hierarchical linear models and measurements applied in this study surpass earlier research on perceived criminal injustice, and they parallel state-of-the-art studies of contextual effects in other venues (see especially Sampson, Raudenbush, and Earls 1997; Sampson, Morenoff, and Earls 1999) by assessing individual differences in school socioeconomic and behavioral composition as well as prior and concurrent individual-level non-normative behavior and police contacts. Notwithstanding these controls, the net effects of school racial integration that we have found remain robust predictors of African American and Latino perceptions of criminal injustice. We find evidence of both similarity and difference in African American and Latino perceptions of criminal injustice, but in the end it is the similarities between these group experiences, rather than the differences, that are perhaps most important.

Still, further research is required. Only a handful of Chicago schools approach the critical levels of white integration required to assess its effects. We have implied that a representation of white students at levels of one-third or more may be close enough to parity to begin to produce mitigating perceptual and attitudinal effects. It is notable that the macro-level controls in this analysis for socioeconomic status and non-normative school behavior parallel the kinds of controls introduced in related educational research (e.g., Johnson, Crosnoe, and Elder 2001:324-25). Chicago, however, is a city with a very distinct as well as important history of racial segregation that may produce unique as well as more generic consequences for adolescents in its public schools. Further elaborations and tests of a comparative conflict theory will usefully examine urban, rural, and suburban jurisdictions with higher levels of racial integration and varying levels of affluence.

It will also be important to develop and assess mediating links in this theoretical approach that specify the kinds of school- and communityconnected experiences and cognitive processes that accompany changing perceptions of criminal injustice. We have found an interesting difference in the effect of mothers' education on youth perceptions among African American and other youth, with some college experience most 
notably resulting in black youth perceiving greater injustice. While we have speculated that this may be a further instance of the "outrage of liberation" discussed in Patterson's research, a weaker and reverse pattern is observed among Latino youth, and more research is needed.

Finally, more work also is needed to assess the behavioral consequences of the perceptions we have explored to determine, for example, whether, and if so how, perceptions of injustice generate different kinds of behavioral (including delinquent and criminal) adaptations or responses, perhaps depending on the levels and sources of the perceptions. Here again, the issue of a tipping point could prove crucial. Such research has the potential to assist policymakers as well as sociologists in developing improved theories and practices linking education and criminal justice, which are two increasingly connected public institutions, for better or worse, in a changing American society.

John Hagan is John D. MacArthur Professor of Sociology and Law at Northwestern University and Senior Research Fellow at the American Bar Foundation. His most recent books are Justice in the Balkans: Prosecuting War Crimes at The Hague Tribunal (University of Chicago Press, 2003) and Northern Passage: American Vietnam War Resisters in Canada (Harvard University Press, 2001), which received the 2003 Albert J. Reiss Award from the Crime, Law and Deviance Section of the American Sociological Association.

Carla Shedd is a Ph.D. Candidate in the Department of Sociology at Northwestern University and is a Pre-Doctoral Fellow at the American Bar Foundation in Chicago. Her research interests include racelethnicity, crime, inequality, and the sociology of law. She has been awarded Pre-Doctoral Fellowships from the American Bar Foundation, the Northwestern University Center for Legal Studies, the National Consortium on Violence Research and Bryn Mawr College.

Monique R. Payne is Assistant Professor in the Department of Sociology at DePaul University. Her research interests focus on the intersection between stratification, education, and racelethnicity.

\section{APPENDIX}

\section{TESTS OF INTERACTIONS BY RACE/ETHNICITY}

Appendix Table Al estimates equations that build on those estimated in Table 2 of the text by adding interaction terms assessing the expec- tation that African American youth in particular may have distinctive responses to police contacts and school composition. We noted earlier that there may be a "familiarity of the expected" that suppresses African American youth responses to contacts with the police. However, Patterson's "paradox of integration" is that an "outrage of liberation" (i.e., in response to a growing awareness of the collective experience of blacks) may emerge with increased exposure to white students in school. We examined these possibilities first with interaction terms representing the nonadditive effects of black student responses to police contacts and black student responses to increased exposure to white students (i.e., as a percentage and percentage-squared of the school population) on perceptions of criminal injustice. We also included an interaction term for black mothers having some college experience, with the expectation that this expanded educational experience as well might be a source of an "outrage of liberation." Latino interaction terms also are included in this table.

The interaction terms were first introduced in pairs and then all together in the four columns of Table Al. In Table A1 only white, black and Latino youth are included. In these analyses, white youth serve as the comparison category. When introduced in pairs, several of the black youth interaction terms are statistically significant: relative to white youth, black students who have contact with the police are less provoked to perceive injustice $(-.146, p<.001)$; black students whose mothers have some college experience are significantly more likely to perceive criminal injustice $(.477, p<.05)$; and black students who are exposed to proportionately more white students in school perceive significantly more injustice $(.079, p<.05)$. When these interaction terms are introduced in the same equation in the last column of Table $\mathrm{Al}$, they remain statistically significant. None of the Latino interaction terms in this table is significant at the .05 level.

Table A2 follows the pattern of Table A1, with the exception that only black and Latino youth are included in the analyses. Black youth are the reference group, which allows us to compare the impact of the variables for black and Latino youth. When introduced in pairs, three of the four Latino youth interaction terms are now statistically significant, so that rela- 
Table A1. Test of Race Interactions on Youth Perception of Injustice

\begin{tabular}{|c|c|c|c|c|}
\hline Variable & Model 1 & Model 2 & Model 3 & Model 4 \\
\hline \multicolumn{5}{|l|}{ Level One: Student } \\
\hline \multirow[t]{2}{*}{ Black } & $2.805 * * *$ & $2.351 * * *$ & $1.668 * * *$ & $1.984 * * *$ \\
\hline & $(.187)$ & $(.167)$ & $(.318)$ & $(.322)$ \\
\hline \multirow[t]{2}{*}{ Latino } & $1.699 * * *$ & $1.665^{* * *}$ & $1.201 * * *$ & $1.262 * * *$ \\
\hline & $(.163)$ & $(.147)$ & $(.318)$ & $(.318)$ \\
\hline \multicolumn{5}{|l|}{ Controls } \\
\hline \multirow[t]{2}{*}{ Male } & -.068 & -.080 & -.083 & -.068 \\
\hline & $(.054)$ & $(.054)$ & $(.054)$ & $(.054)$ \\
\hline \multirow[t]{2}{*}{ Ninth grader } & $-.217 * * *$ & $-.216^{* * *}$ & $-.217 * * *$ & $-.219 * * *$ \\
\hline & $(.051)$ & $(.050)$ & $(.051)$ & $(.051)$ \\
\hline \multirow[t]{2}{*}{ Mom high school graduate } & -.077 & -.052 & -.064 & -.058 \\
\hline & $(.065)$ & $(.065)$ & $(.066)$ & $(.065)$ \\
\hline \multirow[t]{2}{*}{ Mom vocational/trade school education } & -.170 & -.148 & -.173 & -.141 \\
\hline & $(.139)$ & $(.140)$ & (.139) & $(.138)$ \\
\hline \multirow[t]{2}{*}{ Mom some college } & .137 & -.069 & $.155^{*}$ & -.086 \\
\hline & $(.075)$ & $(.180)$ & $(.077)$ & $(.177)$ \\
\hline \multirow[t]{2}{*}{ Mom college graduate } & -.014 & .036 & .002 & .027 \\
\hline & $(.073)$ & $(.073)$ & $(.074)$ & $(.072)$ \\
\hline \multirow[t]{2}{*}{ Mom advanced degree } & -.010 & .034 & -.008 & .023 \\
\hline & $(.094)$ & $(.093)$ & $(.095)$ & $(.094)$ \\
\hline \multirow[t]{2}{*}{ Personal contact with police } & $.387 * * *$ & $.306^{* * *}$ & $.306^{* * *}$ & $.383 * * *$ \\
\hline & $(.023)$ & $(.012)$ & $(.012)$ & $(.022)$ \\
\hline \multirow[t]{2}{*}{ Personal trouble in school } & .006 & .010 & .009 & .007 \\
\hline & $(.009)$ & $(.009)$ & $(.009)$ & $(.009)$ \\
\hline \multicolumn{5}{|l|}{ Level Two: School } \\
\hline \multirow[t]{2}{*}{ Percent white } & $.039 * *$ & $.039 * *$ & -.012 & -.009 \\
\hline & $(.014)$ & $(.014)$ & $(.023)$ & $(.023)$ \\
\hline \multirow[t]{2}{*}{ Percent white squared } & $-.001 *$ & $-.001 *$ & -.00002 & -.00005 \\
\hline & $(.0003)$ & $(.0004)$ & $(.0004)$ & $(.0004)$ \\
\hline \multicolumn{5}{|l|}{ Controls } \\
\hline \multirow[t]{2}{*}{ School 50-80\% low income } & .127 & .135 & .145 & .128 \\
\hline & $(.130)$ & $(.134)$ & $(.134)$ & $(.129)$ \\
\hline \multirow[t]{2}{*}{ School 80-95\% low income } & -.025 & -.037 & -.082 & -.073 \\
\hline & $(.123)$ & $(.126)$ & $(.132)$ & $(.127)$ \\
\hline \multirow[t]{2}{*}{ Average student contact with police } & -.196 & $-.208^{*}$ & -.164 & -.145 \\
\hline & $(.103)$ & $(.104)$ & $(.105)$ & $(.103)$ \\
\hline Average student trouble in school & $-.118^{*}$ & $-.121 *$ & $-.117^{*}$ & $-.110^{*}$ \\
\hline & $(.054)$ & $(.054)$ & $(.052)$ & $(.052)$ \\
\hline Interaction Terms & & & & \\
\hline Black by contact with police & $-.146^{* * *}$ & - & - & $-.140 * * *$ \\
\hline & $(.024)$ & & & $(.023)$ \\
\hline Latino by contact with police & -.024 & - & - & -.020 \\
\hline & $(.025)$ & & & $(.024)$ \\
\hline Black by mom some college & - & $.477 *$ & - & $.463 *$ \\
\hline & & $(.191)$ & & $(.188)$ \\
\hline Latino by mom some college & - & -.010 & - & -.092 \\
\hline & & $(.187)$ & & $(.185)$ \\
\hline Black Slope (Cross-Level Interaction) & & & & \\
\hline Percent white & - & - & $.079 *$ & $.071 *$ \\
\hline & & & $(.031)$ & $(.030)$ \\
\hline Percent white squared & - & - & -.001 & -.001 \\
\hline & & & $(.0007)$ & $(.0007)$ \\
\hline
\end{tabular}


Table A1. (continued)

\begin{tabular}{lcccc}
\hline \hline Variable & Model 1 & Model 2 & Model 3 & Model 4 \\
\hline Latino Slope (Cross-Level Interaction) & & & & \\
$\quad$ Percent white & - & - & .031 & .032 \\
& & & $(.030)$ & $(.030)$ \\
$\quad$ Percent white squared & - & -.0005 & -.0005 \\
& & & $(.0006)$ & $(.0006)$ \\
$\quad$ Constant & $12.361 * * *$ & $12.591 * * *$ & $13.151^{* * *}$ & $12.882^{* * *}$ \\
& $(.277)$ & $(.274)$ & $(.351)$ & $(.350)$ \\
Level One Variance & 7.197 & 7.941 & 7.944 & 7.903 \\
Level Two Variance & .085 & .089 & .086 & .081 \\
Level One Explained Variance & .219 & .139 & .138 & .143 \\
Level Two Explained Variance & .647 & .631 & .643 & .664 \\
Level One N & 17,337 & 17,337 & 17,337 & 17,337 \\
Level Two N & 91 & 91 & 91 & 91 \\
\hline
\end{tabular}

Note : Reference categories: race $=$ white; mom's education $=$ less than high school; school racial composition $=$ mixed; school percent of low income students $=$ less than $50 \%$.

$* p<.05 ; * * p<.01 ; * * * p<.001$ (two-tailed).

Table A2. Test of Race Interactions on Youth Perception of Injustice

\begin{tabular}{|c|c|c|c|c|}
\hline Variable & Model 1 & Model 2 & Model 3 & Model 4 \\
\hline \multicolumn{5}{|l|}{ Level One: Student } \\
\hline Latino & $\begin{array}{c}-1.097 * * * \\
(.095)\end{array}$ & $\begin{array}{l}-.680 * * * \\
(.084)\end{array}$ & $\begin{array}{l}-.469 * * \\
(.130)\end{array}$ & $\begin{array}{l}-.725 * * * \\
(.133)\end{array}$ \\
\hline \multicolumn{5}{|l|}{ Controls } \\
\hline Male & $\begin{array}{c}-.118 \\
(.067)\end{array}$ & $\begin{array}{c}-.122 \\
(.067)\end{array}$ & $\begin{array}{l}-.126 \\
(.066)\end{array}$ & $\begin{array}{c}-.118 \\
(.067)\end{array}$ \\
\hline Ninth grader & $\begin{array}{l}-.231^{* * *} \\
(.050)\end{array}$ & $\begin{array}{l}-.229 * * * \\
(.049)\end{array}$ & $\begin{array}{l}-.230 * * * \\
(.050)\end{array}$ & $\begin{array}{l}-.233 * * * \\
(.050)\end{array}$ \\
\hline Mom high school graduate & $\begin{array}{l}-.083 \\
(.063)\end{array}$ & $\begin{array}{l}-.047 \\
(.063)\end{array}$ & $\begin{array}{l}-.063 \\
(.063)\end{array}$ & $\begin{array}{l}-.058 \\
(.063)\end{array}$ \\
\hline Mom vocational/trade school education & $\begin{array}{c}-.231 \\
(.158)\end{array}$ & $\begin{array}{c}-.191 \\
(.159)\end{array}$ & $\begin{array}{l}-.223 \\
(.158)\end{array}$ & $\begin{array}{l}-.194 \\
(.158)\end{array}$ \\
\hline Mom some college & $\begin{array}{l}.165^{*} \\
(.075)\end{array}$ & $\begin{array}{l}.415 * * * \\
(.080)\end{array}$ & $\begin{array}{l}.194 \\
(.075)\end{array}$ & $\begin{array}{l}.382^{* * *} \\
(.081)\end{array}$ \\
\hline Mom college graduate & $\begin{array}{l}.007 \\
(.079)\end{array}$ & $\begin{array}{l}.072 \\
(.078)\end{array}$ & $\begin{array}{l}.029 \\
(.080)\end{array}$ & $\begin{array}{c}.053 \\
(.079)\end{array}$ \\
\hline Mom advanced degree & $\begin{array}{l}.008 \\
(.104)\end{array}$ & $\begin{array}{l}.077 \\
(.103)\end{array}$ & $\begin{array}{l}025 \\
\quad(.104)\end{array}$ & $\begin{array}{l}.052 \\
(.104)\end{array}$ \\
\hline Personal contact with police & $\begin{array}{l}.250 * * * \\
(.013)\end{array}$ & $\begin{array}{l}.304 * * * \\
(.012)\end{array}$ & $\begin{array}{l}.303 * * * \\
(.012)\end{array}$ & $\begin{array}{l}.252^{* * * *} \\
(.012)\end{array}$ \\
\hline Personal trouble in school & $\begin{array}{c}-.0003 \\
(.009)\end{array}$ & $\begin{array}{l}.003 \\
(.009)\end{array}$ & $\begin{array}{c}.002 \\
(.009)\end{array}$ & $\begin{array}{l}.001 \\
(.01)\end{array}$ \\
\hline \multicolumn{5}{|l|}{ Level Two: School } \\
\hline Percent white & $\begin{array}{l}.046^{* *} \\
(.013)\end{array}$ & $\begin{array}{l}.046^{* *} \\
(.013)\end{array}$ & $\begin{array}{l}.061 * * \\
(.017)\end{array}$ & $\begin{array}{l}.058^{* *} \\
(.016)\end{array}$ \\
\hline Percent white squared & $\begin{array}{c}-.001 * * \\
(.0003)\end{array}$ & $\begin{array}{c}-.001 * * \\
(.0003)\end{array}$ & $\begin{array}{l}-.001 * * \\
(.0004)\end{array}$ & $\begin{array}{l}-.001 * * \\
(.000)\end{array}$ \\
\hline
\end{tabular}


Table A2. (continued)

\begin{tabular}{|c|c|c|c|c|}
\hline Variable & Model 1 & Model 2 & Model 3 & Model 4 \\
\hline \multicolumn{5}{|l|}{ Controls } \\
\hline School 50-80\% low income & $\begin{array}{c}-.021 \\
(.132)\end{array}$ & $\begin{array}{c}-.016 \\
(.131)\end{array}$ & $\begin{array}{l}.015 \\
(.134)\end{array}$ & $\begin{array}{c}-.003 \\
(.135)\end{array}$ \\
\hline School $80-95 \%$ low income & $\begin{array}{l}-.169 \\
(.125)\end{array}$ & $\begin{array}{l}-.183 \\
(.124)\end{array}$ & $\begin{array}{l}-.196 \\
(.131)\end{array}$ & $\begin{array}{l}-.189 \\
(.131)\end{array}$ \\
\hline Average student contact with police & $\begin{array}{c}-.183 \\
(.103)\end{array}$ & $\begin{array}{c}-.192 \\
(.103)\end{array}$ & $\begin{array}{l}-.177 \\
(.104)\end{array}$ & $\begin{array}{l}-.161 \\
(.102)\end{array}$ \\
\hline Average student trouble in school & $\begin{array}{c}-.135^{*} \\
(.052)\end{array}$ & $\begin{array}{c}-.139 * \\
(.052)\end{array}$ & $\begin{array}{c}-.135^{*} \\
(.051)\end{array}$ & $\begin{array}{c}-.127^{*} \\
(.051)\end{array}$ \\
\hline \multicolumn{5}{|l|}{ Interaction Terms } \\
\hline Latino by contact with police & $\begin{array}{l}.122 * * * \\
(.015)\end{array}$ & - & - & $\begin{array}{l}.120 * * * \\
(.015)\end{array}$ \\
\hline Latino by mom some college & - & $\begin{array}{l}-.587 * * * \\
(.109)\end{array}$ & - & $\begin{array}{l}-.565^{* * *} \\
(.109)\end{array}$ \\
\hline \multicolumn{5}{|l|}{ Latino Slope (Cross-Level Interaction) } \\
\hline Percent white & - & - & $\begin{array}{c}-.045^{*} \\
(.021)\end{array}$ & $\begin{array}{c}-.036 \\
(.020)\end{array}$ \\
\hline Percent white squared & - & - & $\begin{array}{c}.0009 \\
(.0007)\end{array}$ & $\begin{array}{c}.0007 \\
(.0005)\end{array}$ \\
\hline Constant & $\begin{array}{c}15.323 * * * \\
(.202)\end{array}$ & $\begin{array}{c}15.124 * * * \\
(.198)\end{array}$ & $\begin{array}{c}15.079 * * * \\
(.208)\end{array}$ & $\begin{array}{c}15.111 * * * \\
(.211)\end{array}$ \\
\hline Level One Variance & 8.078 & 8.098 & 8.105 & 8.065 \\
\hline Level Two Variance & .086 & .086 & .087 & .084 \\
\hline Level One Explained Variance & .101 & .099 & .098 & .103 \\
\hline Level Two Explained Variance & .522 & .522 & .517 & .533 \\
\hline Level One N & 14,966 & 14,966 & 14,966 & 14,966 \\
\hline Level Two N & 90 & 90 & 90 & 90 \\
\hline
\end{tabular}

Note: Reference categories: race $=$ white; mom's education $=$ less than high school; school racial composition $=$ mixed; school percent of low income students $=$ less than $50 \%$.

$* p<.05 ; * * p<.01 ; * * * p<.001$ (two-tailed).

tive to comparable black youth, Latino students who have contact with the police are more provoked to perceive injustice $(.122, p<.001)$; Latino students whose mothers have some college experience are significantly less likely to perceive criminal injustice $(-.587, p<.001)$; and Latino students who are exposed to proportionately more white students in school perceive less (i.e., relative to comparable black youth) injustice $(-.045, p<.05)$. When these interaction terms are all introduced in the same equation in the last column of Table 4, only the percent white effect becomes statistically nonsignificant.

In the main body of the paper, we continue to test the possibility of the differential impact of all the variables on black, white, and Latino youth's perceptions of injustice. We consider each group separately and use confidence intervals to compare the relative impact of all the variables on perceptions of injustice between $\mathrm{racial} / \mathrm{ethnic}$ groups. Such analyses are similar to interaction terms, are easier to present and interpret, and still allow us to test our hypotheses.

\section{REFERENCES}

Anderson, Elijah. 1999. Code of the Streets: Decency, Violence and the Moral Life of the Inner City. New York: Norton.

Bobo, Lawrence and Devon Johnson. 2004. "A Taste for Punishment: Black and White Americans' Views on the Death Penalty and the War on Drugs." Du Bois Review 1:151-80.

Bobo, Lawrence and James Kluegel. 1997. "Status, Ideology, and Dimensions of Whites' Racial Beliefs and Attitudes: Progress and Stagnation.” In Racial Attitudes in the 1990s: Continuity and Change, edited by Steven Tuch and Jack Martin. Westport, CT: Praeger.

Blumstein, Alfred. 1982. "On the Racial Disproportionality of the United States' Prison Population." Journal of Criminal Law \& Criminology 73:1259-70.

Brooks, Richard. 2000. "Fear and Fairness in the 
City: Criminal Enforcement and Perceptions of Fairness in Minority Communities." Southern California Law Review 73:1219-73.

Brooks, Richard and Hackyung Jeon-Slaughter. 2001. "Race, Income and Perceptions of the U.S. Court System." Behavioral Sciences and the Law 19:249-64.

Bryk, Anthony and Stephen Raudenbush. 1992. Hierarchical Linear Models. Newbury Park, CA: Sage.

Carter, David. 1985. "Hispanic Perception of Police Performance: An Empirical Assessment.” Journal of Criminal Justice 13:487-500.

Chambliss, William J. 1999. Power, Politics and Crime. Boulder, CO: Westview.

Chambliss, William and Robert Seidman. 1971. Law, Order and Power. Reading, MA: Addison-Wesley.

Chicago Public Schools. 1997. Reciprocal Records Agreement Between Chicago Public Schools and Chicago Police Department (Board Rep. 705.1, pp. 97-1217-p02). Chicago, IL.

Chicago Sun-Times. 1992. "Police Fire Two Police Officers Over Incident With Teens.” Chicago SunTimes, March 21, p. 4.

Collins, Sharon. 1997. Black Corporate Executives: The Making and Breaking of a Black Middle Class. Philadelphia, PA: Temple University Press.

Consortium on Chicago School Research. 2002. Public Use Data Set: User's Manual. Retrieved 03/05/2005 (www.consortium-chicago.org).

Cose, Ellis. 1994. Rage of a Privileged Class. New York: Harper Collins.

Davis, James. 1959. "A Formal Interpretation of the Theory of Relative Deprivation." Sociometry 22:280-96.

Dawson, Michael. 1994. Behind the Mule: Race and Class in African American Politics. Princeton, NJ: Princeton University Press.

Ellison, Christopher and Daniel Powers. 1994. "The Contact Hypothesis and Racial Attitudes Among Black Americans." Social Science Quarterly 75:385-400.

Entwisle, Doris and Karl Alexander. 1992. "Summer Setback: Race, Poverty, School Composition, and Mathematics Achievement in the First Two Years of School." American Sociological Review 57:72-84.

Feagin, Joe and Melvin Sikes. 1994. Living with Racism: The Black Middle Class Experience. Boston, Massachusetts: Beacon.

Flanagan, Constance and Lonnie Sherrod. 1998. "Youth Political Development." Journal of Social Issues 54:447-56.

Frankenberg, Erica and Chungmei Lee. 2002. "Race in American Public Schools: Rapidly Resegregating School Districts." Cambridge, MA: The Civil Rights Project, Harvard University.

Frankenberg, Erica, Chungmei Lee and Gary Orfield. 2003. "A Multiracial Society with Segregated
Schools: Are We Losing the Dream?" Cambridge, MA: The Civil Rights Project, Harvard University. Hagan, John and Celesta Albonetti. 1982. "Race, Class and the Perception of Criminal Injustice in America." American Journal of Sociology 88:329-355.

Hagan, John and Ilene Bernstein. 1979. "Conflict in Context: The Sanctioning of Draft Resisters, 1963-1976." Social Problems 27:109-22.

Hagan, John, Paul Hirschfield, and Carla Shedd. 2002. "First and Last Words: Apprehending the Social and Legal Facts of an Urban High School Shooting." Sociological Methods \& Research 31:218-54.

Hallinan, Maureen and Richard Williams. 1987. "The Stability of Students' Interracial Friendships." American Sociological Review 52:653-64.

- 1989. Interracial Friendship Choices in Secondary Schools." American Sociological Review 54:67-78.

Hawkins, Darnell. 1987. "Beyond Anomalies: Rethinking the Conflict Perspective on Race and Criminal Punishment." Social Forces 65:719-45.

Henderson, Martha, Francis Cullen, Liqun Cao, Sandra L. Browning, and Renee Kopache. 1997. "The Impact of Race on Perceptions of Criminal Injustice." Journal of Criminal Injustice 25:447-62.

Hirschfield, Paul. 2003. "Preparing for Prison?" Ph.D. dissertation, Department of Sociology, Northwestern University, Evanston, IL.

Hochschild, Jennifer. 1995. Facing Up to the American Dream: Race, Class and the Soul of the Nation. Princeton, NJ: Princeton University Press. Jaccard, James, Robert Turrisi, and Choi Wan. 1990. Interaction Effects in Multiple Regression. Newbury Park, CA: Sage.

Johnson, Monica Kirkpatrick, Robert Crosnoe, and Glen Elder. 2001. "Students' Attachment and Academic Engagement: The Role of Race and Ethnicity." Sociology of Education 74:318-40.

Kennedy, Randall. 1997. Race, Crime and the Law. New York: Pantheon.

LaFree, Gary. 1998. Losing Legitimacy: Street Crime and the Decline of Social Institutions in America. Boulder, CO: Westview.

Liska, Allen, Michell Chamlin, and Mark Reed. 1985. "Testing the Economic Production and Conflict Models of Crime Control." Social Forces 64:119-38.

Mann, Coramae Richey. 1993. Unequal Justice: A Question of Color. Bloomington, IN: Indiana University Press.

Massey, Douglas and Nancy Denton. 1988. "The Dimensions of Racial Segregation.” Social Forces 67:281-315.

-1 1993. American Apartheid: Segregation and the Making of an American Underclass. Cambridge, MA: Harvard University Press. 
Mauer, Marc. 1999. Race to Incarcerate. New York: New Press.

Merton, Robert and Alice Rossi. 1957. "Contributions to the Theory of Reference Group Behavior." In Robert Merton, Social Theory and Social Structure. Glencoe, IL: Free Press.

Mitchell, Michael and Jim Sidanius. 1995. "Social Hierarchy and the Death Penalty: A Social Dominance Perspective." Political Psychology 16:591-619.

Niemi, Richard and Mary Hepburn. 1995. "The Rebirth of Political Socialization." Perspectives on Political Science 24:7-16.

Olszewski, Lori and Darnell Little. 2004. "School Spending Disparity Revealed." Chicago Tribune, March 2.

Orfield, Gary and Chungmei Lee. 2004. "Brown at 50: King's Dream or Plessey's Nightmare?" Cambridge, MA: The Civil Rights Project, Harvard University. Available at www.civilrightsproject (a)harvard.edu.

Patterson, Orlando. 1997. The Ordeal of Integration: Progress and Resentment in America's "Racial" Crisis. New York: Basic.

Peek, Charles W., George D. Lowe, and Jon P. Alston. 1981. "Race and Attitudes Toward Local Police: Another Look." Journal of Black Studies 11:361-74.

Peterson, Ruth and John Hagan. 1984. "Changing Conceptions of Race and Sentencing Outcomes." American Sociological Review 49:56-70.

Portes, Alejandro and Ruben Rumbaut. 2001. Legacies: The Story of the Immigrant Second Generation. Berkeley, CA and New York: University of California Press and Russell Sage Foundation.

Quinney, Richard. 1970. The Social Reality of Crime. Boston, MA: Little, Brown.

Roscigno, Vincent. 1998. "Race and the Reproduction of Educational Disadvantage." Social Forces 76:1033-60.

Runciman, Walter G. 1966. Relative Deprivation and Social Justice: A Study of Attitudes to Social Inequality in Twentieth Century England. London, England: Routledge \& Kegan Paul.

Russell, Kathryn. 1998. The Color of Crime: Racial Hoaxes, White Fear, Black Protectionism, Police Harassment, and Other Macro-aggressions. New York: New York University Press.

Sampson, Robert and Dawn Bartusch. 1998. "Legal Cynicism and (Subcultural?) Tolerance of Deviance: The Neighborhood Context of Racial Differences." Law \& Society Review 32:777-804.

Sampson, Robert and Janet Lauritsen. 1997. "Racial and Ethnic Disparities in Crime and Criminal Justice in the United States." Crime and Justice 311-74.
Sampson, Robert, Jeffrey Morenoff, and Felton Earls. 1999. "Beyond Social Capital: Spatial Dynamics of Collective Efficacy for Children." American Sociological Review 64:633-60.

Sampson, Robert, Stephen Raudenbush, and Felton Earls. 1997. "Neighborhoods and Violent Crime: A Multilevel Study of Collective Efficacy.” Science 15:918-24.

Schelling, Thomas. 1971. "Dynamic Models of Segregation.” Journal of Mathematical Sociology 1:143-86.

Schofield, Janet Ward. 1979. "The Impact of Positively Structured Contact on Intergroup Behavior: Does it Last Under Adverse Conditions?" Social Psychology Quarterly 42:280-84.

Schuman, Howard, Charlotte Steeh, Lawrence Bobo, and Maria Krysan. 1997. Racial Attitudes in America: Trends and Interpretations. Cambridge, MA: Harvard University Press.

Skogan, Wesley, Lynn Steiner, Jill Du Bois, J. Erik Gudell, and Aimee Fagan. 2002. "Community Policing and the 'New Immigrants': Latinos in Chicago." Washington, DC: National Institute of Justice.

Stouffer, Samuel. 1949. The American Soldier, I: Adjustment During Army Life. Princeton, NJ: Princeton University Press.

Suttles, Gerald. 1968. The Social Order of the Slum: Ethnicity and Territory in the Inner City. Chicago, IL: University of Chicago Press.

Tonry, Michael. 1995. Malign Neglect: Race, Crime and Punishment in America. New York: Oxford University Press.

Tuch, Steven and Ronald Weitzer. 1997. "Trends: Racial Differences in Attitudes Toward the Police." Public Opinion Quarterly 61:642-63.

Turk, Austin. 1969. Criminality and the Legal Order. Chicago, IL: Rand McNally.

Turner, J. C., M. A. Hogg, P. J. Oakes, S. D. Reicher, and M. S. Wetherell. 1987. Rediscovering the Social Group: A Self-Categorization Theory. Oxford, England: Blackwell.

Tyler, Tom. 1990. Why People Obey the Law. New Haven, CT: Yale University Press.

Vrij, Aldert and Frans Willem Winkel. 1992. "Cross Cultural Police-Citizen Interactions: The Influence of Race, Beliefs, and Nonverbal Communication on Impression Formation." Journal of Applied Social Psychology 22:1546-59.

Walker, Samuel, Cassia Spohn, and Miriam DeLone. 2000. The Color of Justice: Race, Ethnicity and Crime in America. Stamford, CT: Wadsworth.

Weitzer, Ronald. 1999. "Racialized Policing: Perceptions in Three Neighborhoods." Law \& Society Review 34:301-27.

Weitzer, Ronald and Steven Tuch. 1999. "Race, Class 
and Perceptions of Discrimination by the Police." Crime \& Delinquency 45:494-507.

Wilbanks, William. 1987. The Myth of a Racist Criminal Justice System. Monterey, CA: Brooks/Cole.

Wortley, Scot, John Hagan, and Ross Macmillan. 1997. "Just Des(s)erts? The Racial Polarization of Perceptions of Criminal Injustice." Law \& Society Review 31:637-76.

Young, Alford. 2004. The Minds of Marginalized Black Men: Making Sense of Mobility, Opportunity and Future Life Chances. Princeton, NJ: Princeton University Press. 